\title{
TARIKH MILADI SEPADAN BAGI KENAMPAKAN HILAL RAMADAN DALAM HADIS KURAYB RA BERKAITAN MATLA'
}

\section{The Corresponding Gregorian Date on the Sighting of the Ramadan Hiläl Concerning Matla' in the Hadith of Kurayb RA}

\author{
Muhamad Zakuwa Rodzali* \\ Saadan Man**
}

\begin{abstract}
Hadith Kurayb RA about him being sent by Umm al-Fadl from Madinah to Sham, is one of the main chronicles of the Shäfi $i$ School regarding the outcomes of rukyah hilal which is applicable to the same matla' only. This hadith is narrated in most hadīth books including Sậīh Muslim, Sunan alTirmidhī, Abū Dāwud, al-Nasā̄ $\bar{\imath}$, al-Bayhaqī, alDāruquṭī, Musnad Ahmad bin Hanbāl and Șaḥịh Ibn Khuzaymah, the isnads are authentic and the narrators are thiqah. The reality today is that
\end{abstract}

* Ph.D Candidate, Department of Department of Fiqh and Usul, Academy of Islamic Studies, University of Malaya, 50603, Kuala Lumpur, Malaysia.zakuwa@siswa.um.edu.my

** Associate Professor, Department of Department of Fiqh and Usul, Academy of Islamic Studies, University of Malaya, 50603, Kuala Lumpur, Malaysia.saadan@um.edu.my 
the appreciation of the hadith is difficult to fulfil; although the distance from Madinah to Sham is only around 1055 kilometers it is considered ineffectual to employ the outcomes of rukyah in Sham. However, it is important to have a matching Gregorian date on the appearance of the Ramadan hilal so that the date stated in the hadith could be confirmed. Thus, an analysis from the historical and astronomical perspective was conducted to determine the relevant Gregorian dates. The results of the historical analysis revealed that Kurayb's proclamation could not have occurred earlier than 19H/640M in view of the presence of Muawiyah in Sham and could not be later than $36 \mathrm{H} / 657 \mathrm{M}$ as the last event involving Umm al-Fadl recorded by some historians occurred in that year. The results of the data analysis revealed that the Gregorian date in the hadith that corresponded to the appearance of the crescent moon, April 4, 653M (Thursday) was used to determine the beginning of Ramadan $32 \mathrm{H} / 653 \mathrm{M}$ based on the parameters of the position of the moon including age, altitude, elongation, arc of vision (ARCV) and width $(W)$ all of which were larger at Sham than at Madinah during the rukyah evening, hence it could have been sighted in Sham and not Madinah. It is hoped that this study could provide a clearer understanding to the community on the background of events in the hadith, hence, the proposal for the potential implementation of a more global hijri calendar can be accepted.

Keywords: Hilal, Matla', Arc of Vision, ARCV, Width, W

\section{PENDAHULUAN}

Dalam penentuan awal bulan kamariah, jumhur ulama berpandangan rukyah hilal yang berhasil di sesuatu kawasan terpakai untuk seluruh umat Islam tanpa mengambil kira mațla' (wilayah), sedangkan Mazhab Shafi'i menetapkan ia terpakai 
untuk matla' yang sama sahaja. Antara hujah Mazhab Shafi'i adalah hadis Kurayb RA yang menunjukkan Ibn 'Abbas yang berada di Madinah tidak mengambil kira hasil rukyah di Sham meskipun setelah mendapat laporan keberhasilan rukyah di Sham melalui Kurayb yang diutuskan ke sana dan kembali semula pada penghujung Ramadan kerana setiap tempat tertakluk kepada mațla' masing-masing. Hujah lain Mazhab Shafi'i adalah qiyass perbezaan mațla' bulan dengan perbezaan mațla' matahari yang membawa kepada perbezaan waktu solat seterusnya lojik di mana syarak telah mengaitkan kewajiban berpuasa dengan kenampakan hilal yang membawa kepada perbezaan mula puasa di negerinegeri yang berlainan.

Dalam konteks dunia masa kini, penentuan masuk awal bulan bagi dua tempat dengan berpandukan kepada hadis Kurayb RA yang menjadikan Madinah dan Sham (Damsyik) sebagai rujukan sukar dibuat kerana bandar dan pekan ketika ini berada dalam sempadan negara masing-masing. Sebuah bandar yang terletak tidak jauh dari bandar yang lain dengan negara masingmasing berbeza tetapi matla' mereka sama disebabkan jangka masa terbit dan terbenam hilal kedua-duanya yang hampir sama adalah tertakluk kepada pemerintah negara masing-masing dalam menentukan masuknya awal bulan. Begitu juga kedudukan Madinah dan Damsyik kedua-duanya masih dalam Semenanjung Tanah Arab dengan jarak tidaklah terlalu jauh sekitar 1055 kilometer ${ }^{1}$ menjadikan penyelarasan awal bulan antara negara serantau sekalipun tidak boleh dibuat. Walaupun demikian, adalah penting tarikh miladi sepadan bagi kenampakan hilal Ramadan dalam hadis Kurayb RA dapat ditentukan supaya kefahaman tentang hadis lebih jelas.

\section{METODOLOGI KAJIAN}

Di dalam menyiapkan kajian ini, metodologi kajian yang diguna pakai adalah kajian perpustakaan. Antara perkara yang diteliti termasuklah kesahan mațla' dari sudut syarak. Selain itu, peristiwa dalam hadis dianalisis dari perspektif sejarah untuk menentukan jangka masa diutuskan Kurayb oleh Umm al-Fadl dari Madinah

Distance Calculator, dicapai 5 Mac 2020, https://www.distance.to. 
ke Sham mengambil kira keberadaan Muawiyah di Sham dan keberadaan Ibn 'Abbas di Madinah. Berpandukan kepada data astronomi pula, tarikh miladi sepadan bagi kenampakan hilal dalam hadis berkenaan dapat ditentukan.

\section{KAJIAN LEPAS}

Imron Rosyadi mencadangkan bahawa peristiwa dalam hadis Kurayb RA berlaku pada tahun $45 \mathrm{H} / 665 \mathrm{M} .{ }^{2}$ Asas pertimbangannya adalah jangka waktu yang memungkinkan Muawiyah, Ibn `Abbas dan Kurayb sempat bersama dan juga data astronomi.

Manakala menurut Syamsul Anwar, peristiwa dalam hadis berlaku pada tahun $35 \mathrm{H} / 656 \mathrm{M} .^{3}$ Asas pertimbangannya adalah pada tahun tersebut berlaku ketegangan dalam pemerintahan Saidina Uthman, dari itulah Umm al-Fadl mengutus Kurayb ke Sham menemui Muawiyah supaya memberikan pandangan terhadap Saidina Uthman. Selain itu, Umm al-Fadl sendiri tidak disepakati oleh sejarahwan Islam mengenai tahun kewafatannya, ada yang menyatakan sebelum al-'Abbas wafat sedang sesetengah yang lain menyatakan beliau masih hidup pada awal pemerintahan Saidina 'Ali. Beliau juga mengemukakan analisis data kedudukan bulan pada petang rukyah hilal Ramadan 35H/656M di Damsyik dan Madinah dalam menjelaskan lagi berlakunya peristiwa tersebut pada tahun berkenaan.

Sementara M. Muslih Husein mendapati terdapat dua pandangan berkenaan status hadis Kurayb di mana pelopor pandangan pertama antaranya al-Qurtubi menyatakan hadis tersebut marfuk dan bersumberkan kepada Nabi SAW sementara pelopor pandangan kedua antaranya al-Syaukani menyatakan hadis Kurayb merupakan qawl Ibn `Abbas kerana Ibn `Abbas tidak menyebutkan langsung lafaz perintah Nabi SAW. ${ }^{4}$ Dalam konteks penentuan awal Ramadan, Syawal dan Zulhijah di Indonesia,

2 Imron Rosyadi, "Matlak Global dan Regional", laman sesawang Annual International Conference on Islamic Studies, dicapai 7 Mac 2019, digilib.uinsby.ac.id.

3 Syamsul Anwar, Diskusi dan Korespondensi Kalender Hijriah Global (Yogyakarta: Suara Muhammadiyah, 2014), 2.

4 M. Muslih Husein, "Hadith Kuraib dalam Konsep Rukyatul Hilal," Jurnal Penelitian 13 (2016), 211-224. 
hadis ini yang memperihalkan perbezaan penentuan awal bulan antara Damsyik dan Madinah dengan jarak sekitar 1053 km akan menyebabkan Indonesia terbahagi kepada lima mațla'. Justeru, Kementerian Agama Republik Indonesia menetapkan bahawa Indonesia secara keseluruhan menjadi satu wilayah hukum (wilāyah al-hukm).

\section{MATLA'HILAL DAN KESAHANNYA}

Menurut Lisan al-'Arab, matla' berasal dari al-tulu' yang bermaksud terbit sesuatu. ${ }^{5}$ Darinya terbentuklah perkataan matla' dan mațli' yang merujuk kepada terbit dan tempat terbit. Antara contohnya adalah firman Allah SWT: ${ }^{6}$

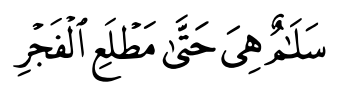

(Surah al-Qadr, 97: 5)

Terjemahan: "Sejahteralah malam (yang berkat) itu hingga terbit fajar (matla' al-fajr)."

Seterusnya firman Allah SWT:

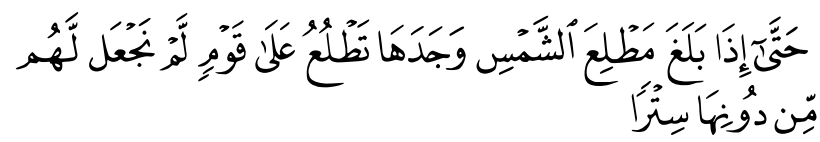

(Surah al-Kahfì, 18: 90)

Terjemahan: "Sehingga apabila ia sampai di daerah matahari terbit (matli' al-fajr)..."

Menurut Mu'jam Lughah al-Fuqaha, akar kata mațla' adalah tala 'a iaitu awal sesuatu. ${ }^{7}$ Sebagai contohnya matla' al-qasidah (permulaan sajak) adalah rumah pertama di dalamnya. ${ }^{8}$ Manakala

5 Ibn Manẓūr, Muhammad ibn Mukarram, Lisān al- 'Arab (Bayrūt: Dār Șādir, 2012), 9:133.

6 Abdullah Basmeih, Tafsir Pimpinan Ar-Rahman kepada Pengertian Al-Qur'an (30) Juz, cet. ke-13 (Kuala Lumpur: Darul Fikir, 2002), 1415.

7 Muhammad Rawwās Qal'ah Ji, Mu 'jam Lughah al-Fuqahà' (Bayrūt:

Dār al-Nafā'is, 1996), 436.

8 Ibid. 
dalam The Encyclopaedia of Islam, matla' bermaksud tempat terbit sesuatu jasad samawi, kebiasaannya bintang, dari ufuk. ${ }^{9}$ Mațla 'juga ada ketikanya bermaksud tempat terbit matahari, yang mana terma masyriq lebih meluas diguna pakai. ${ }^{10}$ Ada ketika juga mațla' bermaksud terbit fajar. ${ }^{11}$

Istilah mațla' hilal atau mațla' yang dikaitkan dengan penyelarasan takwim hijri bermaksud kawasan yang berada pada jangka masa waktu-waktu terbit dan terbenam yang hampir sama. ${ }^{12}$ Sesetengah penulisan menjelaskan maksudnya sebagai batas geografi keberhasilan rukyah. ${ }^{13}$ Maksud-maksud yang dikemukakan secara asasnya saling sokong menyokong antara satu sama lain kerana kawasan yang berada pada jangka masa waktu-waktu terbit dan terbenam yang hampir sama sudah tentu membentuk batas geografi yang sama dari segi keberhasilan rukyah.

Hadis yang menjadi sandaran matla' adalah hadis Kurayb RA adalah sepertimana berikut:

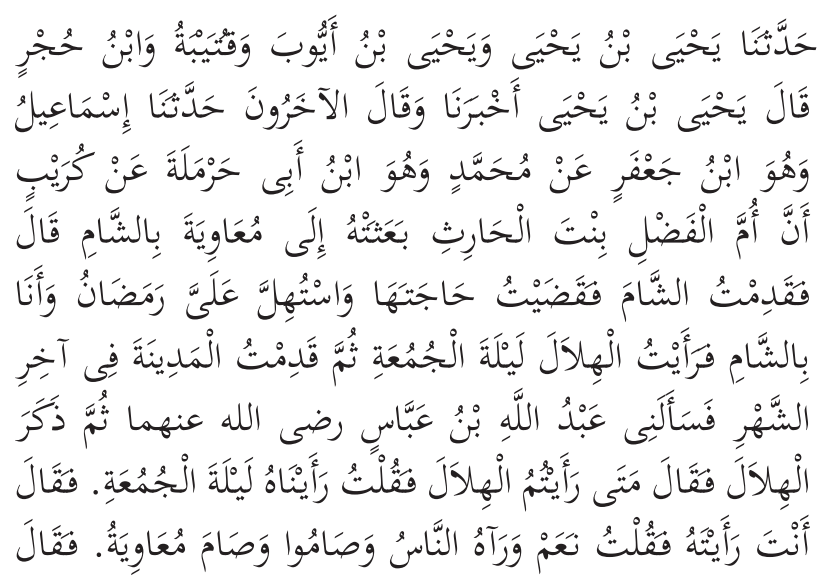

C. E. Bosworth et al., The Encyclopaedia of Islam (Leiden: E. J. Brill, 1991), 839.

10 Ibid.

11 Ibid.

12 Baharrudin Zainal, Ilmu Falak Teori, Praktik dan Hitungan (Kuala Terengganu: Kolej Agama Sultan Zainal Abidin, 2003), 118.

13 Susiknan Azhari, Ensiklopedi Hisab Rukyat (Yogyakarta: Pustaka Pelajar, 2006), 87. 


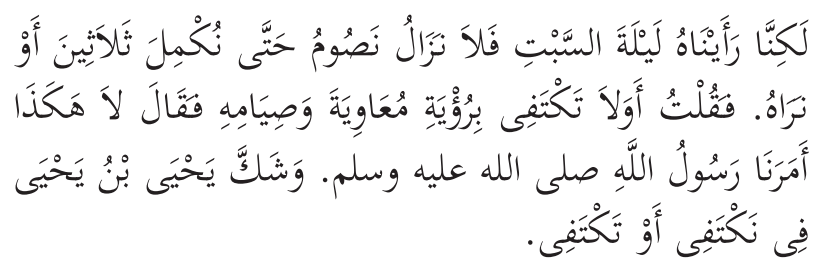

Terjemahan: "Dari Kurayb bahawa Umm al-Fadl telah menghantarnya menemui Mu āwiyah di negeri Sham. Kurayb berkata, "Aku tiba di Sham dan menunaikan hajatnya sedangkan anak bulan Ramadan telah muncul. Aku melihat anak bulan pada malam Jumaat kemudian aku balik ke Madinah alMunawwarah pada akhir bulan, pada masa itu aku ditanya oleh 'Abd Allāh bin 'Abbās yang menyebut tentang anak bulan." Katanya, "Bilakah kamu melihat anak bulan?" Aku menjawab, "Kami melihat pada malam Jumaat!” Ibn 'Abbās bertanya lagi katanya, "Adakah engkau sendiri melihat anak bulan itu?" Aku menjawab, "Ya, orang lain pun melihatnya dan mereka itu berpuasa, Mu'āwiyah turut berpuasa." Ibn 'Abbās berkata, "Kami di sini melihat anak bulan pada malam Sabtu, oleh itu kami terus berpuasa hingga kami sempurnakan 30 hari atau hingga kami melihat anak bulan Syawal." Aku bertanya, "Tidakkah memadai bagi kamu dengan penglihatan anak bulan itu oleh Mu 'āwiyah dan puasanya?" Ibn ‘Abbās menjawab, "Tidak! Beginilah caranya Rasulullah SAW menyuruh kami." 14

14 Al-Nawawī, Muhyī al-Dīn Yahyā bin Sharf, Șaḥ̄ḥ Muslim bi Sharh al-Nawawī, vol. 4 (Qāhirah: Dār al-Fajr li-al-Turāth, 1999), 213, "Kitāb al-Șiyām", no. hadis 1087. 
Hadis di atas telah diriwayatkan oleh Imam Muslim, alTirmidhi ${ }^{15}$, Abu Daud ${ }^{16}$, Ahmad bin Hanbal ${ }^{17}$, al-Nasa'i ${ }^{18}$, alBaihaqi ${ }^{19}$, al-Daraqutni ${ }^{20}$ dan Ibn Khuzaymah. ${ }^{21}$ Dalam Sahih

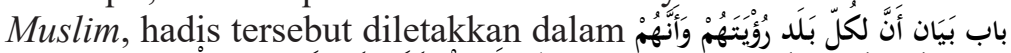

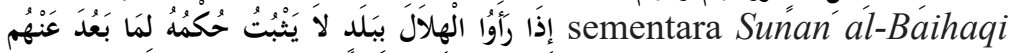

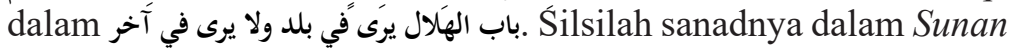
al-Baihaqi adalah dari Yahya bin Yahya dari Ismail bin Jaafar dari Muhammad bin Abi Harmalah dari Kurayb. Manakala dalam

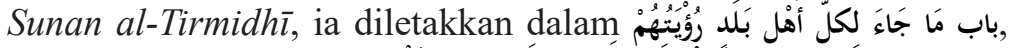

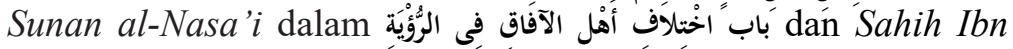

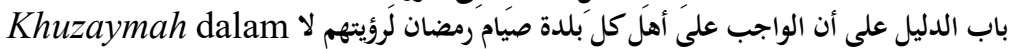
Silsilah sanadnya dalam Sunan al-Tirmidhī, al-Nasa 'i dan Ibn Khuzaymah adalah dari 'Ali bin Hujr dari Ismail bin Jaafar dari Muhammad bin Abi Harmalah dari Kurayb. Al-Tirmidhi menetapkan darjah hadis ini hasan sahih gharib.

Dalam Musnad al-Imam Ahmad bin Hanbal, ia diletakkan dalam Musnad 'Abd Allah bin 'Abbas dengan silsilah sanadnya adalah dari Sulaiman bin Daud al-Hashimi dari Ismail bin Jaafar dari Muhammad bin Abi Harmalah dari Kurayb. Isnad hadis ini sahih dengan Sulaiman bin Daud al-Hashimi seorang yang thiqah manakala Ismail bin Jaafar, Muhammad bin Abi Harmalah dan Kurayb thiqah yang periwayatannya diterima pakai oleh Bukhari dan Muslim. ${ }^{22}$ Sementara dalam Sunan Abu Daud,

15 Al-Tirmidhī, Abū 'Īsā Muḥammad Ibn 'Īsā Ibn Sawrah Ibn Mūsā, Sunan al-Tirmidhī, vol. 3 (Q̄āhirah: Dār al-Ḥad̄̄th, 1999), 49, "Kitāb al-Sawm", no. hadis 693.

16 Abū Dāwud, Sunan Abū Dāwud, vol. 2 (Qāhirah: Dār al-Ḥadīth, 1999), 1005, "Kitāb al-Șawm", no. hadis 2332.

17 Ahmad bin Hanbal, Musnād Ahmad bin Hanbal, no. hadis 2789 (Bayrūt: Mu'assasah al-Risālah, 1999), 5:10.

18 Al-Nasā'̂̄, Sunan al-Nasā' '̄, vol. 3 (Bayrūt: Dār al-Kutub al'Ilmiyyah, 1995), 98, “Kitāb al-Șiyām”, no. hadis 2111.

19 Al-Bayhaqī, Sunan al-Bayhaqī, vol. 4 (Bayrūt: Dār al-Kutub al'Ilmiyyah, 1999), 420, "Kitāb al-Șiyām", no. hadis 8205.

20 Al-Dāraqutnī, Sunan al-Dāraqutn̄̄, vol. 1(Bayrūt: Dār al-Kutub al'Ilmiyyah, 1996), 151, "Kitāb al-Șiyām”, no. hadis 2191.

21 Ibn Khuzaymah, Șahịh Ibn Khuzaymah, vol. 3 (Bayrūt: al-Maktab al-Islāmī, 1992), 205, "Kitāb al-Siyām", no. hadis 1916.

22 Aḥmad bin Ḥanbāl, Musnad Aḥmad bin Hanbāl, vol. 5 (Bayrūt: Mu'assasah al-Risālah, 1999), 10, no. hadis 2789. 
باب إذا رؤي الهلال في بلد قبل الآخرين بليلة hadis tersebut diletakkan dalam dengan silsilah sanadnya adalah dari Musa bin Ismail dari Ismail bin Jaafar dari Muhammad bin Abi Harmalah dari Kurayb. Abu Daud menetapkan darjah hadis ini sahih. Manakala dalam Sunan al-Daraqutni, ia diletakkan dalam باب الشهادة على رؤية الهلال dengan silsilah sanadnya adalah dari Shuraih bin al-Nu'man dari Ismail bin Jaafar dari Muhammad bin Abi Harmalah dari Kurayb. AlDaraqutni menetapkan isnad hadis sebagai sahih.

Sebagaimana yang dijelaskan oleh ahli-ahli hadis bahawa isnad hadis ini sahih tetapi melalui jalan gharib. Ibn 'Abbas meriwayatkan hadis kepada Kurayb. Kurayb meriwayatkan kepada Muhammad bin Abi Harmalah. Seterusnya Muhammad bin Abi Harmalah kepada Ismail bin Jaafar. Dari Ismail bin Jaafar, sanadnya masyhur kerana ramai perawi yang meriwayatkan seterusnya iaitu Yahya bin Yahya, Yahya bin Ayyub, Qutaibah, 'Ali bin Hujr, Sulaiman bin Daud al-Hashimi, Musa bin Ismail dan Shuraih bin al-Nu'man.

Justeru, bagaimanakah perincian isnad hadis tersebut? Siapakah Kurayb, Muhammad bin Abi Harmalah dan Ismail bin Jaafar? Nama sebenar Kurayb adalah Kurayb bin Abi Muslim alHashimi. ${ }^{23}$ Beliau sempat bersama dengan 'Uthman bin 'Affan RA. Beliau meriwayatkan hadis dari Ibn `Abbas, Umm al-Fadl, 'Aisyah, Umm Salamah, Umm Hani dan sebahagian lagi sahabat. Meriwayatkan pula dari beliau Sulaiman bin Yasar, Makhramah bin Sulaiman, Muhammad bin Abi Harmalah dan lain-lain. AlWaqidi menyatakan beliau wafat di Madinah tahun 98H/716M pada penghujung pemerintahan Sulaiman bin 'Abd al-Malik. AlNasa'i menyifatkannya seorang yang thiqah. Manakala Ibn Sa'ad menyifatkannya sebagai seorang yang thiqah dan baik hadisnya. Sementara Muhammad bin Abi Harmalah adalah Muhammad bin Abi Harmalah al-Qurasyi Abu 'Abd Allah al-Madani. ${ }^{24}$ Beliau meriwayatkan hadis antaranya dari Salim bin Abdullah bin 'Umar, Sulaiman bin Yasar dan Kurayb. Meriwayatkan pula dari beliau Ismail bin Jaafar, Sufyan bin 'Uyainah, Malik bin Anas dan lain-

23 Al-'Asqalān̄i, Shihāb al-Dīn Abū al-Faḍl Aḥmad bin Hajr, Tahzīb alTahzīb, vol. 4 (Bayrūt: Dār Iḥyā’ al-Turāth al-'Arab̄̄, 1993), 591.

24 Al-Mazzī, Jamāl al-Dīn Abī al-Hajjāj Yūsuf, Tahzīb al-Kamāl fì Asmā' al-Rijāl, vol. 6 (Bayrūt: Mu'assasah al-Risālah, 1998), 274. 
lain. Ibn Sa ad menyatakan beliau wafat pada awal pemerintahan Abu Jaafar al-Mansur. ${ }^{25}$ Al-Nasa'i menyifatkannya seorang yang thiqah. Ismail bin Jaafar pula adalah Ismail bin Jaafar bin Abi Kathir al-Ansari. ${ }^{26}$ Beliau telah meriwayatkan hadis dari Rabi ah kemudian diriwayatkan pula dari beliau oleh Sa id bin Sulaiman, Yahya bin Ayyub, 'Ali bin Hujr dan seterusnya yang lain. Al-Haitham bin Kharijah menyatakan bahawa beliau wafat di Baghdad pada tahun 180H/796M. ${ }^{27}$ Ibn Ma in menyatakan bahawa beliau seorang yang thiqah.

Sehubungan itu, apakah hadis ini tertolak semata-mata kerana gharibnya? Perlu diingat bahawa terdapat banyak hadis yang diriwayatkan dalam Sunan Sittah yang gharib. Termasuklah juga hadis berikut: ${ }^{28}$

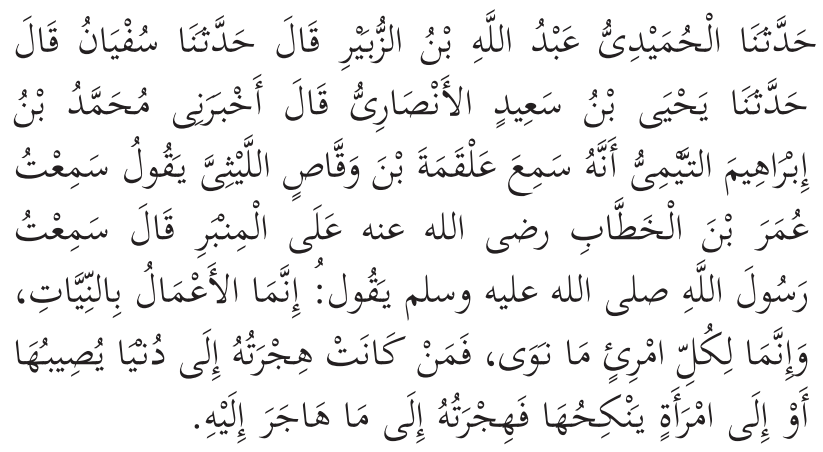

Terjemahan: "Sesungguhnya setiap perbuatan tergantung niatnya. Dan sesungguhnya setiap orang (akan dibalas) berdasarkan apa yang dia niatkan. Barangsiapa yang hijrahnya kerana ingin mendapatkan (keredaan) Allah dan Rasul-Nya, maka hijrahnya kepada (keredaan) Allah dan Rasul-Nya. Dan

25 Al-'Asqalānī, Shihāb al-Dīn Abū al-Faḍl Aḥmad bin Hajr, Tahzīb alTahzīb, vol. 5, 73 .

26 Al-Munz̄̄r, 'Abd al-Raḥmān bin Ab̄̄ Hātim Muhammad bin Idrīs bin, Kitāb al-Jarh wa al-Ta'dīl, vol. 2 (Qāhirah: Maktabah Dār alKutub al-Mișriyyah, t.t.), 162.

27 Al-'Asqalānī, Shihāb al-Dīn Abū al-Faḍl Aḥmad bin Hajr, Tahzīb alTahzīb, vol. 1, 183.

28 Hammām 'Abd al-Raḥīm Sa'īd, al-Tamhīd fì 'Ulūm al-Hadīth ('Ammān: Dār al-Furqān li al-Nashr, 1992), 55. 
barangsiapa yang hijrahnya kerana menginginkan kehidupan yang layak di dunia atau kerana wanita yang ingin dinikahinya maka hijrahnya (akan bernilai sebagaimana) yang dia niatkan." ${ }^{29}$

Hadis di atas diriwayatkan oleh seorang sahabat sahaja iaitu Umar bin al-Khattab. Umar bin al-Khattab meriwayatkan kepada 'Alqamah bin Waqqas al-Laithi. Seterusnya 'Alqamah bin Waqqas al-Laithi kepada Muhammad bin Ibrahim al-Taimi. Dari Muhammad bin Ibrahim al-Taimi kepada Yahya bin Said al-Ansari. Berseorangannya perawi yang meriwayatkan hadis ini berterusan dari sanad pertama iaitu Umar bin al-Khattab sehinggalah sanad Yahya bin Said al-Ansari. Kemudian selepasnya baharulah diriwayatkan oleh sejumlah perawi.

Hukum beramal dengan hadis gharib terletak kepada status hadis itu sendiri. Sekiranya ia hadis sahih, maka boleh beramal dan berhujah dengannya. Hadis Kurayb adalah hadis sahih yang diriwayatkan dalam Sahih Muslim, dinilai sahih oleh Abu Daud dan al-Daraqutni sementara al-Tirmidhi menilainya sebagai hasan sahih gharib, isnad hadisnya sahih dan kesemua perawinya thiqah.

Sesetengah fuqaha antaranya al-Shawkani membangkitkan persoalan mengenai jawaban Ibn Abbas لاَ هَكَذَا أمَرَنَا رَسُولُ اللَّه صلى الله (Tidak! Beginilah caranya Rasulullah SAW menyuruh

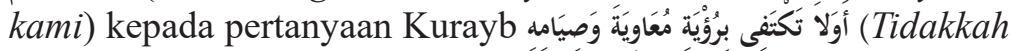
memadai bagi kamu dengan penglihatan anak bulan itu oleh Mu'āwiyah dan puasanya?). Al-Syaukani berpandangan bahawa pernyataan tersebut merupakan ijtihad Ibn Abbas sendiri yang tidak boleh dijadikan hujah. Justeru, ijtihad berkenaan tidak boleh menyanggah pandangan jumhur ulama bahawa hasil rukyah hilal meliputi seluruh umat Islam berasaskan kepada hadis Abu Hurairah berikut:

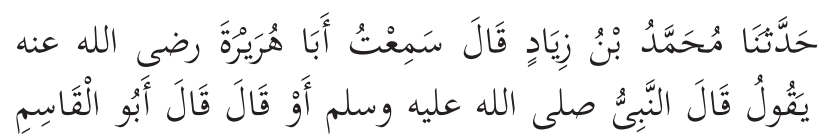

29 Al-'Asqalānī, Aḥmad bin 'Alī bin Hajr, Fatḥ al-Bārī Sharḥ Șậ̄ḥ al-Bukhārī (Riyāḍ: Dār al-Salām, 2000), 12, "Kitāb Bad'i al-Waḥy”, no. hadis 1 . 


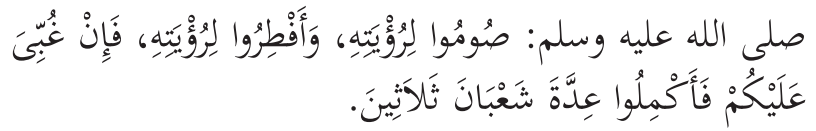

Terjemahan: "Telah menceritakan kepada kami Muhammad bin Ziyad bahawa beliau mendengar Abu Hurayrah RA berkata Rasulullah SAW atau Abu alQasim bersabda, "Berpuasalah kamu kerana melihatnya (hilal) dan berbukalah kamu kerana melihatnya (hilal). Sekiranya (penglihatan) kamu tertutup oleh awan maka sempurnakanlah bulan Syaaban 30 hari." 30

Dalam menilai isu berbangkit ini, berpandukan kriteria penentuan hadis sekiranya terdapat sahabat yang meriwayatkan dengan suatu lafaz antaranya "Rasulullah SAW telah bersabda begini" atau "Rasulullah SAW telah memerintahkan begini" atau "Rasulullah SAW telah memutuskan demikian" atau "beliau telah melarang mengerjakan ini". Oleh yang demikian, jumhur ulama berpendapat bahawa semua lafaz tersebut menjadi hujah bahawa sahabat tersebut telah meriwayatkan dari Nabi SAW. Berdasarkan penilaian terhadap kredibiliti Ibn 'Abbas selaku sahabat Nabi SAW pula, adalah sesuatu yang tidak mungkin bagi Ibn 'Abbas menyandarkan ijtihad beliau atas nama Nabi SAW. ${ }^{31}$

Kesimpulannya dalam perbincangan berkaitan kesahan matla' dari sudut syarak, mațla' mempunyai sandaran yang jelas dalam al-Quran. Begitu juga dalam hadis, memandangkan

30 Al-'Asqalānī, Aḥmad bin 'Alī bin Hajr, Fatḥ al-Bārī Sharḥ Ṣah̄ịh al-Bukhārī, vol. 4, 154, "Kitāb al-Șawm”, no. hadis 1909.

31 Al-Bayhaqī, al-Sunan al-Kubrā, vol. 4 (Bayrūt: Dār al-Kutub al'Ilmiyyah, 1999), 421. 
tidak ada sebab untuk dipertikai status hadis Kurayb berkenaan. ${ }^{32}$ Walau bagaimanapun, dalam konteks dunia masa kini di mana ruang lingkup kehidupan harian manusia adalah lebih luas, ada yang melepasi jarak 1,000 kilometer malah ada yang merentasi benua sama ada untuk tujuan perniagaan, pentadbiran atau apaapa tujuan lain, penghayatan berpandukan hadis Abu Hurairah mengenai hasil rukyah hilal terpakai kepada seluruh umat Islam menjadi lebih praktikal.

Rajah 1: Peta Kedudukan Madinah, Arab Saudi dan Damsyik, Syria

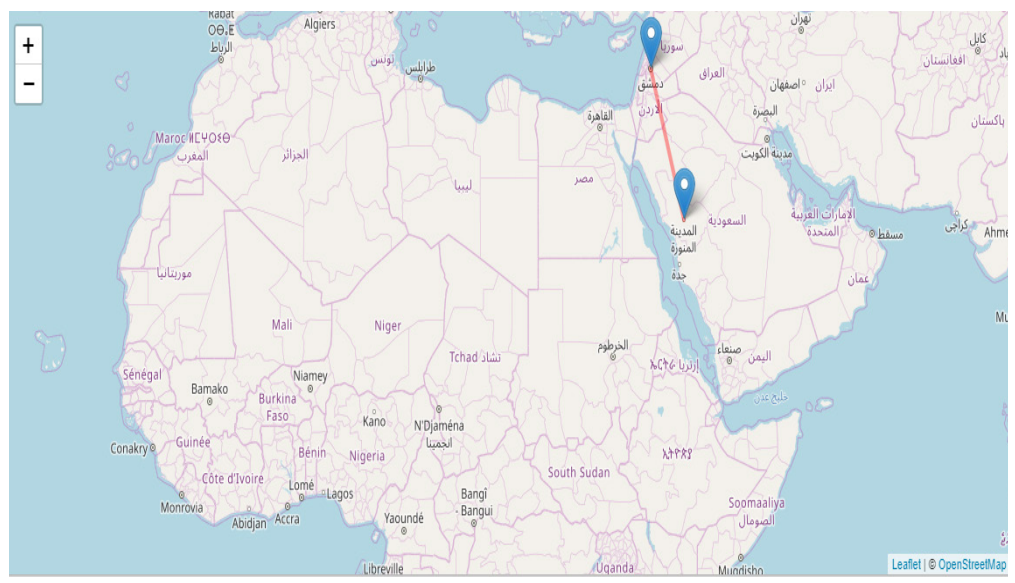

Sumber: Google Maps

32 Secara ringkas, Mazhab Shafi'i berpegang dengan pandangan bahawa hasil rukyah hilal hanya boleh diguna pakai oleh kawasan yang berada dalam mațla'yang sama sahaja. Keluasan mațla'tersebut pula diperselisihkan oleh fuqaha' mazhab dengan yang paling luas beza matahari terbenam pada dua tempat kadar $8^{\circ}$ atau negeri-negeri yang jaraknya kurang daripada $889 \mathrm{~km}$. Menurut pendapat ini, sekiranya maksimal ketinggian hilal tanggal satu bulan hijriah adalah $8^{\circ}$, maka lama hilal di atas ufuk sekitar $8 \times 4$ minit $=32$ minit. Perbezaan waktu 32 minit di daerah Khatulistiwa adalah bersamaan dengan $(32 / 60) \times 15$ darjah x $(40,000 \mathrm{~km} / 360)=889 \mathrm{~km}$. Lihat Bahagian Hal Ehwal Islam, Jabatan Perdana Menteri, "Ke Arah Penyelarasan Mațla" (Kertas Kerja, Musyawarah Jawatankuasa Penyelarasan Rukyah dan Taqwim Islam Negara Brunei Darussalam, Republik Indonesia, Malaysia dan Singapura Kali Ke-3, 1-2 Jun 1992), 1-22. 


\section{JANGKA MASA BERLAKUNYA PERISTIWA DALAM HADIS KURAYB RA}

Jangka masa berlakunya peristiwa dalam hadis Kurayb RA digariskan oleh dua perkara berikut:

a) Kesempatan bersama kesemua empat tokoh yang terlibat dalam hadis merangkumi Kurayb yang diutuskan dari Madinah ke Sham, Umm al-Fadl yang mengutusnya, Ibn `Abbas anak kepada Umm al-Fadl dan Muawiyah sama ada sepanjang awal Ramadan hingga awal Syawal atau awal Ramadan sahaja.

Tidak mungkin peristiwa tersebut berlaku semasa salah seorang terlibat telah lama wafat.

b) Tempoh Muawiyah mentadbir Sham.

Berkenaan tempoh Muawiyah mentadbir Sham, dalam al-Bidāyah wa al-Nihāyah menyatakan bahawa pembukaan Damsyik yang merupakan ibu kota Sham berlaku semasa zaman pemerintahan Khalifah Umar al-Khattab pada tahun 14H/635M, sementara menurut sesetengah pandangan yang lain menyatakan ia berlaku pada tahun $13 \mathrm{H} / 634 \mathrm{M} \cdot{ }^{33}$ Muawiyah menjawat Gabenor seterusnya Khalifah di sana dari tahun $19 \mathrm{H}-60 \mathrm{H}(640 \mathrm{M}-680 \mathrm{M}){ }^{34}$

Berkaitan dengan riwayat hidup tokoh lain pula, nama sebenar Umm al-Fadl adalah Lubabah binti al-Harith al-Hilaliah, isteri kepada al-'Abbas bin 'Abd al-Muttalib. ${ }^{35}$ Beliau merupakan wanita terawal memeluk Islam selepas Khadijah. Tarikh wafatnya tidak tercatat secara sepakat dalam sejarah Islam. Ibn Hibban menyatakan bahawa beliau wafat semasa pemerintahan Khalifah 'Uthman bin 'Affan sebelum suaminya al-'Abbas bin 'Abd al-Muttalib. ${ }^{36}$ Khalifah 'Uthman bin 'Affan memerintah dari Muharram 24H/644M hingga Zulhijjah 35H/656M. Ada juga catatan yang menunjukkan Umm al-Fadl masih hidup sehingga

33 Ibn Kathīr, al-Bidāyah wa al-Nihāyah, vol. 4 (Bayrūt: Dār alMa'rifah, 2001), 26.

34 Ibid, 7:103.

35 Al-Mazzī, Jamāl al-Dīn Abī al-Hajjāj Yūsuf, Taḩzīb al-Kamāl fì Asmā'al-Rijāl, vol. 8, 575.

36 Al-Zahab̄i, Siyār A 'lām al-Nubalā', vol. 2 (Bayrūt: Mu'assasah alRisalah, $1413 \mathrm{H}), 315$. 
ke awal pemerintahan Khalifah 'Ali menjelang Perang Jamal pada tahun $36 \mathrm{H} / 657 \mathrm{M} .{ }^{37}$ Sementara al- Abbas wafat pada tahun $32 \mathrm{H} / 653 \mathrm{M}$ dalam bulan Rejab atau bulan Ramadan. ${ }^{38}$ Sebahagian yang lain menyatakan beliau wafat pada tahun $33 \mathrm{H} / 654 \mathrm{M}$, ada juga menyatakan $34 \mathrm{H} / 655 \mathrm{M} \cdot{ }^{39}$

Nama penuh beliau adalah Kurayb bin Abī Muslim al-Hāshimī. Tarikh lahir beliau tidak tercatat secara jelas. Beliau sempat bersama dengan 'Uthmān RA. Al-Wāqidī menyatakan beliau wafat di Madinah tahun $98 \mathrm{H} / 716 \mathrm{M}$ pada akhir pemerintahan Sulaiman bin 'Abd al-Malik. Ibn Sa'ad, Ibn Mu'ayyan dan alNasā'̂̄ menyifatkannya sebagai thiqah. ${ }^{40}$

Sementara Ibn `Abbas merupakan anak kepada Umm al-Fadl dan al-'Abbas, lahir tiga tahun sebelum hijrah Rasulullah SAW dari Makkah ke Madinah dan wafat pada tahun 68H/687M. ${ }^{41}$

Dari catatan-catatan sejarah di atas, dimaklumi bahawa peristiwa dalam hadis Kurayb RA berlaku antara tahun $19 \mathrm{H}-36 \mathrm{H}$ (640M-657M). Terdapat pengkaji iaitu Imron Rosyadi yang mencadangkan bahawa peristiwa dalam hadis Kurayb berlaku pada tahun $45 \mathrm{H} / 665 \mathrm{M} .{ }^{42}$ Asas pertimbangannya adalah jangka waktu yang memungkinkan Kurayb, Ibn 'Abbas dan Muawiyah sempat bersama dan juga data astronomi. Berpandukan hadis, adalah jelas bahawa Umm al-Fadl yang mengutus Kurayb ke Sham, justeru Umm al-Fadl semestinya perlu diambil kira sebagai salah seorang yang sepatutnya sempat bersama Kurayb, Muawiyah dan Ibn Abbas. Pada penelitian penulis, peristiwa dalam hadis Kurayb tidak mungkin berlaku selepas tahun $36 \mathrm{H} / 657 \mathrm{M}$ memandangkan Umm al-Fadl dilaporkan wafat sebelum al-'Abbas yang dilaporkan wafat pada tahun $32 \mathrm{H} / 653 \mathrm{M}$ atau menurut catatan para

37 Al-Ṭabarī, Abū Ja 'far Muḥammad Ibn Jarīr, Tarīkh al-Ṭabarī, vol. 3 (Bayrūt: Dār al-Kutub al-'Ilmiyyah, t.t.), 8.

38 Al-Mazzī, Jamāl al-Dīn Abī al-Ḥajjāj Yūsuf, Taḥzīb al-Kamāl fì Asmā'al-Rijāl, 174.

39 Ibid.

40 Al-Mazzī, Jamāl al-Dīn Abī al-Hajjāj Yūsuf, Taḥzīb al-Kamāl fì Asmā' al-Rijāl, vol. 6, 166.

41 Ibid, 4, 178.

42 Imron Rosyadi, "Matlak Global dan Regional", laman sesawang Annual International Conference on Islamic Studies, dicapai 7 Mac 2019, digilib.uinsby.ac.id. 
sejarahwan lain pada tahun $33 \mathrm{H} / 654 \mathrm{M}$ atau $34 \mathrm{H} / 655 \mathrm{M}$ dan juga catatan sesetengah sejarahwan bahawa Umm al-Fadl masih hidup selewat-lewatnya menjelang Perang Jamal pada tahun 36H/657M. Dengan Kurayb dinyatakan wafat pada tahun $98 \mathrm{H} / 716 \mathrm{M}$, maka sudah tentu umurnya panjang kerana beza antara 98H/716M dengan 36H/657M sahaja sudah menjangkau 62 tahun. Manakala beza antara 98H/716M dengan $19 \mathrm{H} / 640 \mathrm{M}$ adalah 79 tahun. Sudah tentu juga Kurayb tidak diutuskan ke Sham pada ketika umurnya sangat muda. Walau bagaimanapun, untuk tujuan analisis data, kedudukan bulan yang dikeluarkan untuk kedua-dua kota Damsyik dan Madinah adalah dari 19H-45H (640M-665M) seperti dalam Jadual 1 di Lampiran A.

\section{KEMUNGKINAN TAHUN SEPADAN DENGAN PERISTIWA DALAM HADIS KURAYB RA}

Berpandukan kepada perbandingan analisis data kedudukan bulan bagi penentuan awal Ramadan untuk Damsyik, Syria dengan Madinah, Arab Saudi dari tahun 19H-45H (640M-665M), dapatlah dikeluarkan kemungkinan tahun sepadan dengan peristiwa dalam hadis Kurayb RA seperti dalam Jadual 2 di Lampiran B.

Dari Jadual 2, didapati hanya tujuh tahun sahaja yang berkemungkinan berlakunya peristiwa dalam hadis Kurayb dari aspek astronomi iaitu 19H/640M, 24H/645M, 27H/648M, $32 \mathrm{H} / 653 \mathrm{M}, 35 \mathrm{H} / 656 \mathrm{M}, 40 \mathrm{H} / 661 \mathrm{M}$ dan $43 \mathrm{H} / 663 \mathrm{M}$. Dari tujuh tahun yang berkemungkinan ini pula, tahun $19 \mathrm{H} / 640 \mathrm{M}$ boleh diketepikan memandangkan tiada sebarang catatan berkait Kurayb dinyatakan dalam kitab-kitab sirah pada tahun berkenaan. Dengan Kurayb dilaporkan wafat pada tahun $98 \mathrm{H} / 716 \mathrm{M}$ juga, sekiranya beliau diutus pada tahun 19H/640M ketika usianya belasan atau dua puluhan maka tentunya umur Kurayb mencecah hampir 100 tahun semasa beliau wafat.

Tahun 24H/645M dan 27H/648M juga diketepikan memandangkan pada tarikh-tarikh berkenaan, umur hilal di Damsyik dan Madinah kedua-duanya lebih 34j dan 36j masingmasing dengan altitud hilal lebih besar di Madinah berbanding Damsyik sementara elongasi lebih sedikit di Damsyik berbanding Madinah. Justeru, tiada penjelasan yang boleh diberikan mengapa hilal kelihatan di Damsyik tetapi tidak di Madinah. Begitu juga 
sekiranya Kurayb telah lahir sekalipun pada tahun-tahun ini, beliau masih kecil untuk dijadikan sebagai perutusan.

Jadual 3: Data Kedudukan Bulan Tahun 24H/645M

\begin{tabular}{|c|c|c|c|c|c|c|c|c|c|c|}
\hline Lokasi & $\begin{array}{c}\text { Hilal } \\
\text { Ramadan }\end{array}$ & Ijtimak & $\begin{array}{l}\text { Tarikh } \\
\text { Analisis }\end{array}$ & $\begin{array}{l}\text { Mthri } \\
\text { T'bnm }\end{array}$ & $\begin{array}{c}\text { Bulan } \\
\text { T'bnm }\end{array}$ & $\begin{array}{c}\text { Umur Bulan } \\
\text { j m }\end{array}$ & Altitud & Elongasi & ARCV & $\underset{0,,}{\mathbf{W}}$ \\
\hline Damsyik & $\begin{array}{l}24 \mathrm{H} / \\
645 \mathrm{M}\end{array}$ & $\begin{array}{l}\text { 08:15 LT } \\
\text { 29 Jun }\end{array}$ & $\begin{array}{l}30 \text { Jun } \\
\text { (Khamis) }\end{array}$ & $18: 51$ & $20: 22$ & 3437 & 145717 & 190700 & 161118 & 000056 \\
\hline Madinah & & $\begin{array}{l}\text { 09:15 LT } \\
\text { 29 Jun }\end{array}$ & $\begin{array}{l}30 \text { Jun } \\
\text { (Khamis) }\end{array}$ & $19: 16$ & $20: 45$ & 3401 & 160149 & 184410 & 173518 & 000053 \\
\hline
\end{tabular}

Sumber: Perisian Accurate Times Versi 5.6

Jadual 4: Data Kedudukan Bulan Tahun 27H/648M

\begin{tabular}{|c|c|c|c|c|c|c|c|c|c|c|}
\hline Lokasi & $\begin{array}{c}\text { Hilal } \\
\text { Ramadan }\end{array}$ & Ijtimak & $\begin{array}{c}\text { Tarikh } \\
\text { Analisis }\end{array}$ & $\begin{array}{l}\text { Mthri } \\
\text { T'bnm }\end{array}$ & $\begin{array}{l}\text { Bulan } \\
\text { T'bnm }\end{array}$ & $\begin{array}{c}\text { Umur Bulan } \\
\text { j m }\end{array}$ & Altitud & Elongasi & $\underset{\circ,,,}{\mathbf{A R C V}}$ & W, \\
\hline Damsyik & $\begin{array}{l}27 \mathrm{H} / \\
648 \mathrm{M}\end{array}$ & $\begin{array}{c}\text { 05:58 LT } \\
\text { 28: Mei }\end{array}$ & $\begin{array}{c}29 \text { Mei } \\
\text { (Khamis) }\end{array}$ & $18: 41$ & $20: 25$ & 3644 & 162944 & 185121 & 180035 & 000053 \\
\hline Madinah & & $\begin{array}{c}\text { 06:58 LT } \\
\text { 28: Mei }\end{array}$ & $\begin{array}{c}29 \mathrm{Mei} \\
\text { (Khamis) }\end{array}$ & 19:08 & $20: 43$ & 3610 & 164457 & 183224 & 183740 & 000051 \\
\hline
\end{tabular}

Sumber: Perisian Accurate Times Versi 5.6

Tahun 40H/661M dan 43H/663M juga diketepikan memandangkan tiada catatan sirah berkaitan Umm al-Fadl melainkan yang berakhir dengan tahun 36H/657M. Begitu juga semasa pemerintahan Khalifah `Ali, Ibn `Abbas dilantik sebagai Gabenor di Basrah, kemudian beliau pindah ke Makkah seterusnya Taif sehinggalah beliau wafat.

Hanya ada dua kemungkinan yang tinggal iaitu tahun $32 \mathrm{H} / 653 \mathrm{M}$ dan 35H/656M. Menurut Syamsul Anwar, peristiwa tersebut berlaku pada tahun $35 \mathrm{H} / 656 \mathrm{M} .{ }^{43}$ Asas pertimbangannya adalah pada tahun tersebut berlaku ketegangan dalam pemerintahan Saidina 'Uthman, dari itulah Umm al-Fadl mengutus Kurayb ke Sham untuk menemui Muawiyah supaya memberikan pandangan terhadap Saidina 'Uthman. Selain itu, Umm al-Fadl sendiri tidak disepakati oleh sejarahwan Islam mengenai tahun kewafatannya, ada yang menyatakan sebelum al-'Abbas wafat sedangkan sesetengah yang lain menyatakan beliau masih hidup sehingga awal pemerintahan Saidina `Ali.

43 Syamsul Anwar, Diskusi dan Korespondensi Kalender Hijriah Global, 2. 
Pada penelitian penulis, berasaskan catatan sejarah bahawa Umm al-Fadl wafat menurut sebahagian sejarahwan sama ada sebelum al-'Abbas wafat yang diperselisihkan pada tahun $32 \mathrm{H} / 653 \mathrm{M}, 33 \mathrm{H} / 654 \mathrm{M}$ atau $34 \mathrm{H} / 655 \mathrm{M}$ dan menurut sebahagian sejarahwan lain pada awal zaman pemerintahan Saidina 'Ali, peristiwa dalam hadis Kurayb berlaku pada tahun 32H/653M. Ia berasaskan kepada data kedudukan bulan Ramadan 32H/653M di mana altitud dan elongasi juga lengkok kejatuhan, arc of vision (ARCV) dan kelebaran anak bulan, width (W), kesemuanya lebih besar di Damsyik berbanding Madinah, umur hilal di Damsyik dan Madinah masing-masing 25j 06m dan $24 \mathrm{j} 47 \mathrm{~m}$, susul masa bulan terbenam selepas matahari terbenam masing-masing 74 minit dan 65 minit, menjelaskan mengapa hilal kelihatan di Damsyik tetapi tidak di Madinah.

Jadual 5: Data Kedudukan Bulan Tahun 32H/653M:

\begin{tabular}{|c|c|c|c|c|c|c|c|c|c|c|}
\hline Lokasi & $\begin{array}{c}\text { Hilal } \\
\text { Ramadan }\end{array}$ & Ijtimak & $\begin{array}{c}\text { Tarikh } \\
\text { Analisis }\end{array}$ & $\begin{array}{l}\text { Mthri } \\
\text { T'bnm }\end{array}$ & $\begin{array}{l}\text { Bulan } \\
\text { T'bnmm }\end{array}$ & $\underset{\text { j m m }}{\text { Umur Bulan }}$ & Altitud & Elongasi & ARCV & W, \\
\hline Damsyik & $\begin{array}{l}32 \mathrm{H} / \\
653 \mathrm{M}\end{array}$ & $\begin{array}{c}\text { 16:57 LT } \\
\text { 3 April }\end{array}$ & $\begin{array}{c}4 \text { April } \\
\text { (Khamis) }\end{array}$ & $18: 03$ & $19: 17$ & 2506 & 123050 & 141154 & 142913 & 000032 \\
\hline Madinah & & $\begin{array}{c}\text { 17:57 LT } \\
3 \text { April }\end{array}$ & $\begin{array}{l}\text { 4 April } \\
\text { (Khamis) }\end{array}$ & $18: 44$ & $19: 49$ & 2447 & 120203 & 140153 & 140535 & 000031 \\
\hline
\end{tabular}

Sumber: Perisian Accurate Times Versi 5.6

Berpandukan data kedudukan bulan Ramadan 35H/656M melalui Jadual 6, altitud bulan lebih besar sedikit di Madinah berbanding Damsyik sedang elongasi di Madinah lebih kecil sedikit berbanding Damsyik. Manakala umur hilal di Damsyik dan Madinah masing-masing 36j 58m dan 36j 49m dan susul masa bulan terbenam selepas matahari terbenam masing-masing 82 minit dan 75 minit, ia sudah sangat besar untuk kelihatan dengan mata kasar di kedua-dua lokasi berkenaan.

Jadual 6: Data Kedudukan Bulan Tahun 35H/656M:

\begin{tabular}{|c|c|c|c|c|c|c|c|c|c|c|}
\hline Lokasi & $\begin{array}{c}\text { Hilal } \\
\text { Ramadan }\end{array}$ & Ijtimak & $\begin{array}{c}\text { Tarikh } \\
\text { Analisis }\end{array}$ & $\begin{array}{l}\text { Mthri } \\
\text { T'bnm }\end{array}$ & $\begin{array}{l}\text { Bulan } \\
\text { T'bnm }\end{array}$ & $\underset{\mathbf{j} \text { m }}{\text { Umur Bulan }}$ & Altitud & Elongasi & ARCV & $\underset{.,}{\mathbf{W}}$ \\
\hline Damsyik & $\begin{array}{l}35 \mathrm{H} / \\
656 \mathrm{M}\end{array}$ & $\begin{array}{c}04: 43 \mathrm{LT} \\
2 \mathrm{Mac}\end{array}$ & $\begin{array}{c}3 \mathrm{Mac} \\
\text { (Khamis) }\end{array}$ & $17: 41$ & 19:03 & 3658 & 144537 & 163538 & 164321 & 000039 \\
\hline Madinah & & $\begin{array}{c}05: 43 \mathrm{LT} \\
2 \mathrm{Mac}\end{array}$ & $\begin{array}{c}3 \mathrm{Mac} \\
\text { (Khamis) }\end{array}$ & $18: 32$ & $19: 47$ & 3649 & 144550 & 163051 & 164427 & 000039 \\
\hline
\end{tabular}

Sumber: Perisian Accurate Times Versi 5.6 
Penentuan tahun 32H/653M sebagai tahun berlakunya peristiwa dalam hadis Kurayb juga berasaskan kepada kriteria susul masa terbenam yang dicadangkan oleh Mohammad Ilyas, di mana susul masa bulan terbenam selepas matahari terbenam bagi latitud $30^{\circ}$ yang memungkinkan kenampakan adalah $46 \pm 4$ minit. Dalam ketamadunan Babylon, kenampakan berhasil apabila bulan terbenam 48 minit selepas matahari terbenam. ${ }^{44}$ Manakala lengkok pemisahan bulan dengan matahari $12^{\circ}$ sudah cukup untuk membolehkan kenampakan.

Secara ringkas, data kedudukan bulan pada petang $29 \mathrm{hb}$ Syaaban $32 \mathrm{H} / 653 \mathrm{M}$ yang sudah memadai untuk membolehkan kenampakan dengan mata kasar di Damsyik dan Madinah menjadi faktor penentuan tahun $32 \mathrm{H} / 653 \mathrm{M}$ sebagai tahun berlakunya peristiwa dalam hadis Kurayb. Keberhasilan rukyah di Damsyik dan ketidakberhasilan rukyah di Madinah besar kemungkinan terjadi disebabkan oleh faktor cuaca. Sedang pada tahun $35 \mathrm{H} / 656 \mathrm{M}$ bulan sudah cukup besar dan lama berada di atas ufuk untuk tidak memungkinkan ketidakkenampakan di keduadua tempat. Selain itu, sebab perutusan Kurayb dari Madinah ke Damsyik tidak dinyatakan dalam hadis, justeru untuk mengaitkan suasana politik semasa sekitar tahun $35 \mathrm{H} / 656 \mathrm{M}$ dengan peristiwa dalam hadis Kurayb RA adalah sukar dibuktikan.

Daripada analisis data kedudukan bulan bagi penentuan awal Ramadan untuk tempoh dua puluh tujuh tahun yang telah dibuat juga didapati altitud bulan pada petang $29 \mathrm{hb}$ bukan sentiasa lebih tinggi di Damsyik berbanding Madinah meskipun Damsyik lebih ke barat dari Madinah. Ada ketikanya altitud bulan lebih tinggi di Madinah. Dengan jarak antara Damsyik dan Madinah sekitar 1055 kilometer, lebih besar daripada 889 kilometer begitu juga perbezaan matahari terbenam antara kedua-dua tempat berkenaan melebihi kadar $8^{\circ}$, maka sudah tentu mațla' kedua-duanya adalah berbeza.

Secara ringkasnya, pada tahun $32 \mathrm{H} / 653 \mathrm{M}$ dahulu sebahagian umat Islam mungkin boleh menerima kemasukan awal bulan yang berbeza antara Damsyik dengan Madinah meskipun kedua-dua tempat tersebut masih dalam Semenanjung Tanah Arab, akan tetapi

44 Mohammad Ilyas, Kalendar Islam Antarabangsa (Kuala Lumpur: Dewan Bahasa dan Pustaka, 1999), 36. 
dengan realiti dunia masa kini yang menyaksikan perkembangan pesat sistem pemetaan, telekomunikasi dan pengangkutan maka perbezaan dalam kemasukan awal bulan antara dua lokasi sedemikian sukar diterima.

\section{KESIMPULAN}

Hadis Kurayb RA berstatus sahih, isnad hadisnya sahih dan kesemua perawinya thiqah. Tarikh miladi sepadan bagi kenampakan hilal dalam hadis ini adalah pada 4 April $653 \mathrm{M}$ (Khamis) untuk penentuan Ramadan 32H/653M. Penentuan awal bulan berpandukan hadis ini dalam konteks dunia masakini sukar dibuat. Dengan jarak antara Madinah, Arab Saudi dan Damsyik, Syria sekitar 1055 kilometer menyebabkan Ibn 'Abbas tidak mengambil kira hasil rukyah di Damsyik untuk pelaksanaan di Madinah, sudah tentu Malaysia yang mempunyai jarak antara bandar paling barat iaitu Langkawi, Kedah dengan bandar paling timur iaitu Lahad Datu, Sabah melebihi jarak antara Madinah dan Damsyik iaitu 2011 kilometer $^{45}$ menghadapi kesulitan untuk berpegang dengan hadis tersebut. Hadis tersebut sesuai dilaksanakan dalam konteks silam dengan jarak perjalanan terbatas dan ruang lingkup kehidupan harian manusia tidak luas.

\section{RUJUKAN}

Al-'Asqalān̄̄, Aḥmad bin 'Alī bin Ḥajr. Fath al-Bārī Sharh Șaḥīh al-Bukhārī. Riyāḍ: Dār al-Salām, 2000.

Al-'Asqalānī, Shihāb al-Dīn Abū al-Faḍl Aḥmad bin Hajr, Tahzīb al-Tahzīb, vol. 4. Bayrūt: Dār Ihyyā' al-Turāth al-'Arabī, 1993.

Abdullah Basmeih. Tafsir Pimpinan Ar-Rahman kepada Pengertian Al-Qur'an (30) Juz, cet. ke-13. Kuala Lumpur: Darul Fikir, 2002.

Abū Dāwud. Sunan Abū Dāwud, vol. 2. Qāhirah: Dār al-Ḥadīth, 1999.

Aḥmad bin Hanbāl, Musnad Ahmad bin Hanbāl, vol. 5. Bayrūt: Mu'assasah al-Risālah, 1999.

45 Distance Calculator, dicapai 5 Mac 2020, distance.to. 
Bahagian Hal Ehwal Islam, Jabatan Perdana Menteri. "Ke Arah Penyelarasan Mațla"'. Kertas Kerja, Musyawarah Jawatankuasa Penyelarasan Rukyah dan Taqwim Islam Negara Brunei Darussalam, Republik Indonesia, Malaysia dan Singapura Kali Ke-3, 1-2 Jun 1992.

Baharrudin Zainal. Ilmu Falak Teori, Praktik dan Hitungan. Kuala Terengganu: Kolej Agama Sultan Zainal Abidin, 2003.

Al-Bayhaqī. al-Sunan al-Kubrā, vol. 4. Bayrūt: Dār al-Kutub al'Ilmiyyah, 1999.

C. E. Bosworth et al. The Encyclopaedia of Islam. Leiden: E. J. Brill, 1991.

Distance Calculator, dicapai 5 Mac 2020, https://www.distance.to. Hammām 'Abd al-Rahīm Sa'īd. al-Tamhìd fì 'Ulūm al-Hadìth. 'Ammān: Dār al-Furqān li al-Nashr, 1992.

Ibn Kathīr. al-Bidāyah wa al-Nihāyah, vol. 4. Bayrūt: Dār alMa'rifah, 2001.

Ibn Khuzaymah. Șahịh Ibn Khuzaymah, vol. 3. Bayrūt: al-Maktab al-Islāmī, 1992.

Ibn Manzūr, Muḥammad ibn Mukarram. Lisān al- 'Arab. Bayrūt: Dār Șādir, 2012.

Imron Rosyadi. "Matlak Global dan Regional", laman sesawang Annual International Conference on Islamic Studies, dicapai 7 Mac 2019, digilib.uinsby.ac.id.

Kamus Dewan. Ed. Ke-4. Kuala Lumpur: Dewan Bahasa dan Pustaka, 2005.

M. Muslih Husein. "Hadith Kuraib dalam Konsep Rukyatul Hilal." Jurnal Penelitian 13 (2016), 211-224.

Al-Mazzī, Jamāl al-Dīn Abī al-Ḥajjāj Yūsuf. Taḥzīb al-Kamāl fì Asmà 'al-Rijāl, vol. 6. Bayrūt: Mu'assasah al-Risālah, 1998.

Muhammad Rawwās Qal'ah Ji. Mu'jam Lughah al-Fuqahā'. Bayrūt: Dār al-Nafā' is, 1996.

Al-Munzīr, 'Abd al-Raḥmān bin Ab̄̄ Hātim Muḥammad bin Idrīs bin. Kitāb al-Jarh wa al-Ta'dīl, vol. 2. Qāhirah: Maktabah Dār al-Kutub al-Mișriyyah, t.t. 
Al-Nasā'̄i. Sunan al-Nasā'̄̄, vol. 3. Bayrūt: Dār al-Kutub al'Ilmiyyah, 1995.

Al-Nawawī, Muhȳī al-Dīn Yahyā bin Sharf. Șaḥ̄h Muslim bi Sharh al-Nawawī, vol. 4. Qāhirah: Dār al-Fajr li-al-Turāth, 1999.

Susiknan Azhari. Ensiklopedi Hisab Rukyat. Yogyakarta: Pustaka Pelajar, 2006.

Syamsul Anwar. Diskusi dan Korespondensi Kalender Hijriah Global. Yogyakarta: Suara Muhammadiyah, 2014.

Al-Ṭabarī, Abū Ja'far Muhammad Ibn Jarīr. Tarīkh al-Tabarī, vol. 3. Bayrūt: Dār al-Kutub al-'Ilmiyyah, t.t.

Al-Tirmidhī, Abū 'Īsā Muhammad Ibn 'Īsā Ibn Sawrah Ibn Mūsā. Sunan al-Tirmidhī, vol. 3. Qāhirah: Dār al-Hadīth, 1999.

Al-Zahabī. Siyār A 'lām al-Nubalā', vol. 2. Bayrūt: Mu'assasah al-Risalah, $1413 \mathrm{H}$. 
Tarikh Miladi Sepadan bagi Kenampakan Hilal Ramadan dalam Hadis Kurayb RA Berkaitan Mațla'

\begin{tabular}{|c|c|c|c|c|c|c|c|c|c|}
\hline 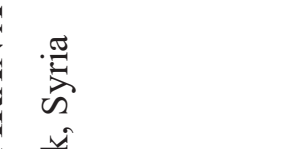 & $3 \vdots$ & $\begin{array}{l}n \\
8 \\
8 \\
8\end{array}$ & $\begin{array}{l}1 \\
8 \\
8 \\
8\end{array}$ & $\begin{array}{l}\vec{N} \\
\overline{0} \\
\dot{8}\end{array}$ & $\begin{array}{l}9 \\
\vdots \\
0 \\
8\end{array}$ & $\begin{array}{l}1 \\
\delta \\
8 \\
8 \\
8\end{array}$ & $\begin{array}{l}\overline{8} \\
8 \\
8\end{array}$ & $\begin{array}{l}\text { m } \\
\stackrel{8}{8} \\
8\end{array}$ & $\begin{array}{l}m \\
\tilde{8} \\
8\end{array}$ \\
\hline 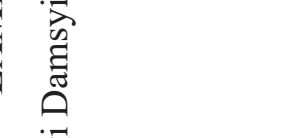 & 己: & $\begin{array}{l}\text { กै } \\
\text { ஸे } \\
8\end{array}$ & $\begin{array}{l}0 \\
\text { 1 } \\
\text { 5 } \\
0\end{array}$ & 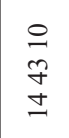 & $\begin{array}{l}5 \\
n \\
n\end{array}$ & $\begin{array}{l}m \\
\text { an } \\
\text { à }\end{array}$ & $\begin{array}{l}\text { J } \\
8 \\
8 \\
8\end{array}$ & \begin{tabular}{l}
$n$ \\
$\stackrel{n}{2}$ \\
\multirow{2}{0}{}
\end{tabular} & $\begin{array}{l}\stackrel{ \pm}{e} \\
\stackrel{\simeq}{\simeq}\end{array}$ \\
\hline 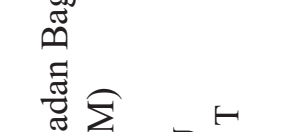 & 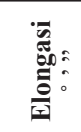 & $\frac{n}{2}$ & $\begin{array}{l}m \\
\stackrel{p}{+} \\
\infty \\
\infty \\
\infty\end{array}$ & 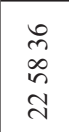 & $\begin{array}{l}\text { ले } \\
\text { ले } \\
\text { ते }\end{array}$ & $\frac{\substack{N \\
\frac{1}{0}}}{2}$ & 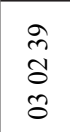 & $\begin{array}{l}\vec{n} \\
\pm \\
n\end{array}$ & $\begin{array}{l}n \\
i n \\
\pm\end{array}$ \\
\hline 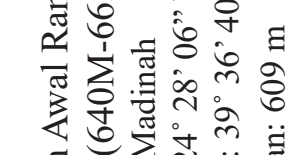 & 总: & $\begin{array}{l}n \\
\infty \\
\infty \\
m \\
0\end{array}$ & $\begin{array}{l}\text { t } \\
\text { i } \\
\text { है } \\
\text { o }\end{array}$ & $\begin{array}{l}5 \\
0 \\
0 \\
0 \\
0\end{array}$ & $\stackrel{\substack{+m}}{i n}$ & $\begin{array}{l}0 \\
+ \\
0 \\
0 \\
0\end{array}$ & 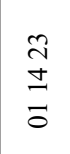 & $\begin{array}{l}\stackrel{2}{\infty} \\
\stackrel{8}{\circ} \\
\stackrel{2}{0}\end{array}$ & $\begin{array}{l}\stackrel{0}{1} \\
\frac{m}{0}\end{array}$ \\
\hline 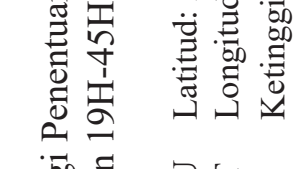 & 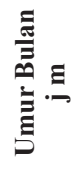 & 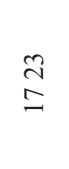 & $\begin{array}{l}8 \\
=\end{array}$ & $\begin{array}{l}\text { ते } \\
\vec{\nabla}\end{array}$ & $\begin{array}{l}\text { ñ } \\
\text { o }\end{array}$ & $\begin{array}{l}n \\
\tilde{8} \\
8\end{array}$ & సे & $\begin{array}{l}\text { in } \\
\text { On }\end{array}$ & 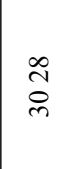 \\
\hline 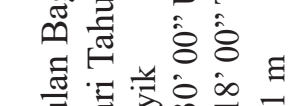 & 炡 & 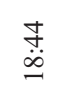 & $\stackrel{\widetilde{N}}{\ddot{\sigma}}$ & 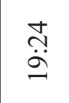 & 仓̊. & $\begin{array}{l}\stackrel{+}{+} \\
\dot{0}\end{array}$ & $\stackrel{m}{\ddot{a}}$ & $\stackrel{\infty}{\ddot{a}}$ & 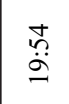 \\
\hline 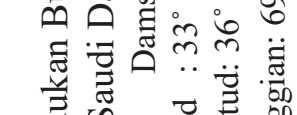 & 䓃恶 & $\stackrel{\sim}{\dddot{\infty}}$ & 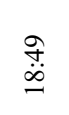 & $\underset{\ddot{\infty}}{\overrightarrow{\dot{\phi}}}$ & $\begin{array}{l}\stackrel{\infty}{+} \\
\stackrel{\infty}{-}\end{array}$ & $\begin{array}{l}\stackrel{\sim}{a} \\
\ddot{\infty}\end{array}$ & $\begin{array}{l}\stackrel{n}{n} \\
\infty\end{array}$ & 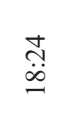 & $\begin{array}{l}\stackrel{\infty}{n} \\
\infty \\
\infty\end{array}$ \\
\hline 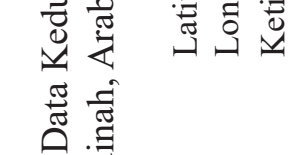 & 童育 & 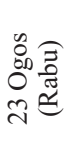 & 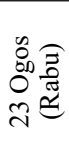 & 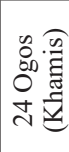 & 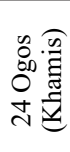 & 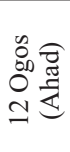 & 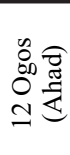 & 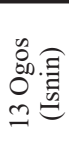 & 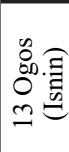 \\
\hline 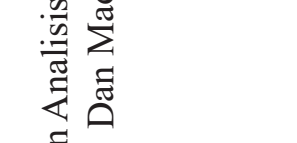 & 曾 & $\begin{array}{ll}5 & 0 \\
a & 8 \\
a & 0 \\
\dot{8} & 2\end{array}$ & 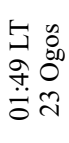 & & & 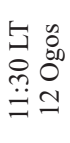 & 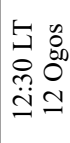 & & \\
\hline 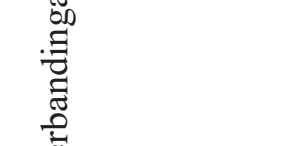 & 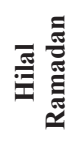 & 兊主 & & & & 茎斿 & & & \\
\hline 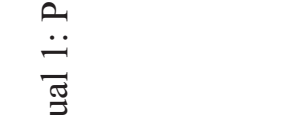 & 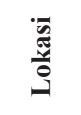 & 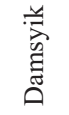 & $\begin{array}{l}\frac{\pi}{\pi} \\
\stackrel{\pi}{\Xi} \\
\sum\end{array}$ & 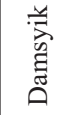 & 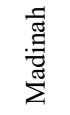 & 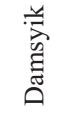 & 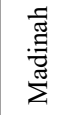 & 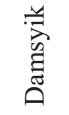 & 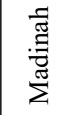 \\
\hline$r$ & $\overline{\bar{\theta}}$ & - & & & & $\nu$ & & & \\
\hline
\end{tabular}


Jurnal Fiqh, Vol. 18 No. 1 (2021) 67-102

\begin{tabular}{|c|c|c|c|c|c|c|c|c|c|c|c|c|}
\hline$a$ & & & & un & & & & $A$ & & & & $\omega$ \\
\hline 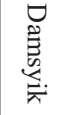 & 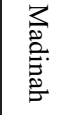 & 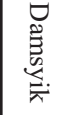 & 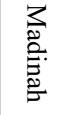 & 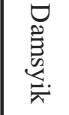 & 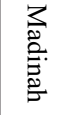 & 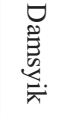 & 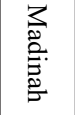 & 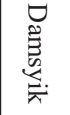 & 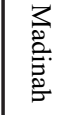 & 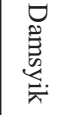 & 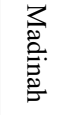 & 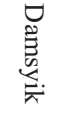 \\
\hline $\begin{array}{l}\text { 童 } \\
3 \\
3\end{array}$ & & & & 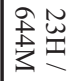 & & & & $\begin{array}{l}\text { 咅 } \\
3 \\
3\end{array}$ & & & & 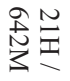 \\
\hline 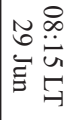 & & & 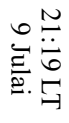 & 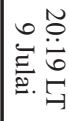 & & & 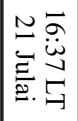 & 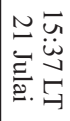 & & & $\begin{array}{l}-\vec{a} \\
0 \\
0 \\
0 \\
0 \\
0 \\
0\end{array}$ & 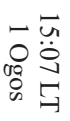 \\
\hline 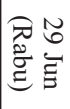 & 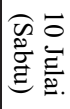 & 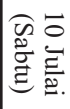 & 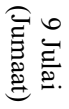 & 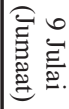 & 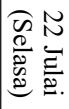 & 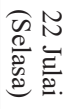 & 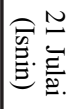 & 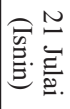 & 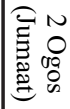 & 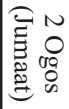 & 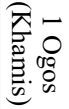 & 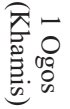 \\
\hline$\underset{\dot{\omega}}{\dot{\omega}}$ & $\stackrel{\overrightarrow{\breve{u}}}{\stackrel{\vec{u}}{ }}$ & $\begin{array}{l}\ddot{\infty} \\
\dot{t}\end{array}$ & $\stackrel{\vec{\varphi}}{\dot{u}}$ & $\begin{array}{l}\vec{\infty} \\
\ddot{t}\end{array}$ & $\stackrel{\vec{\varphi}}{\stackrel{\sim}{\sim}}$ & $\begin{array}{l}\vec{\infty} \\
\ddot{\dot{\omega}}\end{array}$ & $\stackrel{\vec{\sim}}{\stackrel{N}{N}}$ & $\begin{array}{l}\ddot{\infty} \\
\ddot{+}\end{array}$ & $\begin{array}{l}\text { ঢ̆ } \\
\dot{\circ}\end{array}$ & $\begin{array}{l}\vec{\infty} \\
\dot{\dot{u}}\end{array}$ & $\begin{array}{l}\overrightarrow{0} \\
\dot{\theta}\end{array}$ & $\begin{array}{l}\vec{\infty} \\
\dot{\sim} \\
\sigma\end{array}$ \\
\hline $\begin{array}{l}\overrightarrow{0} \\
\dot{\mathcal{U}}\end{array}$ & $\begin{array}{l}\stackrel{N}{0} \\
\dot{\infty}\end{array}$ & $\begin{array}{l}\vec{\bullet} \\
\dot{+}\end{array}$ & 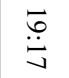 & $\begin{array}{l}\vec{\infty} \\
\ddot{\ddot{n}}\end{array}$ & 苍 & $\underset{\dot{\infty}}{\vec{\infty}}$ & $\begin{array}{l}\overrightarrow{\dot{\omega}} \\
\stackrel{\dot{\omega}}{\mathbf{w}}\end{array}$ & $\begin{array}{l}\vec{\infty} \\
\ddot{\infty}\end{array}$ & 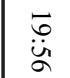 & $\begin{array}{l}\vec{\bullet} \\
\dot{\sim} \\
u\end{array}$ & 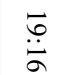 & $\begin{array}{l}\dot{\infty} \\
\dot{\infty}\end{array}$ \\
\hline$\underset{\omega}{\sigma}$ & $\frac{N}{u_{n}}$ & $\begin{array}{l}\stackrel{N}{N} \\
\text { W }\end{array}$ & $\begin{array}{l}\dot{1} \\
\text { O } \\
\text { \& }\end{array}$ & $\begin{array}{l}\dot{b} \\
\dot{0}\end{array}$ & 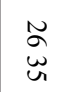 & $\begin{array}{l}\text { N } \\
\text { O }\end{array}$ & $\begin{array}{l}\text { i } \\
\text { a }\end{array}$ & 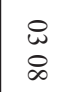 & $\begin{array}{l}\tilde{a} \\
\text { U్b }\end{array}$ & $\underset{N}{N}$ & $\begin{array}{l}\ddot{\omega} \\
\&\end{array}$ & $\begin{array}{l}\tilde{W} \\
\tilde{U}\end{array}$ \\
\hline $\begin{array}{l}\not \\
+ \\
\stackrel{+}{0} \\
\omega \\
\infty\end{array}$ & $\begin{array}{l}\triangleright \\
\infty \\
\pm \\
\text { Un }\end{array}$ & $\begin{array}{l}\triangleright \\
\infty \\
\sim \\
\tilde{\perp} \\
\perp\end{array}$ & $\begin{array}{l}\stackrel{1}{N} \\
\stackrel{ \pm}{ \pm} \\
=\end{array}$ & $\begin{array}{l}\dot{b} \\
\omega \\
\vec{\omega} \\
\text { on }\end{array}$ & $\begin{array}{l}8 \\
\sigma \\
\omega\end{array}$ & $\begin{array}{l}\triangleright \\
w \\
\omega \\
\pm\end{array}$ & $\begin{array}{l}8 \\
N \\
w \\
\omega\end{array}$ & $\begin{array}{l}8 \\
\text { un } \\
\text { un } \\
w\end{array}$ & $\begin{array}{l}\infty \\
\dot{u} \\
u \\
=\end{array}$ & $\begin{array}{l}9 \\
\text { Un } \\
\text { L } \\
\pm\end{array}$ & $\begin{array}{l}8 \\
\omega \\
\sigma\end{array}$ & $\begin{array}{l}8 \\
w \\
+ \\
N \\
w\end{array}$ \\
\hline $\begin{array}{l}\stackrel{8}{ } \\
\text { No } \\
w \\
w\end{array}$ & $\begin{array}{l}0 \\
\text { un } \\
u \\
\vec{N}\end{array}$ & $\begin{array}{l}= \\
\bar{u} \\
\bar{\omega}\end{array}$ & $\begin{array}{l}\stackrel{\omega}{ } \\
w \\
u \\
0\end{array}$ & $\begin{array}{l}\infty \\
\infty \\
\infty \\
N\end{array}$ & $\begin{array}{l}= \\
\text { ज્ } \\
\omega \\
\omega\end{array}$ & $\begin{array}{l}\bar{N} \\
\Xi \\
\text { Un }\end{array}$ & 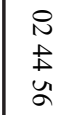 & $\begin{array}{l}\text { i } \\
\pm \\
\pm \\
\pm\end{array}$ & $\begin{array}{l}\vec{N} \\
\text { u } \\
\pm\end{array}$ & $\begin{array}{l}\bar{N} \\
N \\
\text { U } \\
\text { N }\end{array}$ & $\begin{array}{l}\text { O } \\
\bar{U} \\
8\end{array}$ & 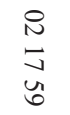 \\
\hline $\begin{array}{l}\stackrel{8}{ } \\
\text { w } \\
\text { La }\end{array}$ & $\begin{array}{l}\sigma \\
\underset{\omega}{\omega} \\
\omega \\
\omega\end{array}$ & $\begin{array}{l}8 \\
u \\
u \\
b\end{array}$ & 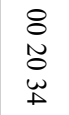 & $\begin{array}{l}\odot \\
\Xi \\
\infty\end{array}$ & $\begin{array}{l}\text { ஏ } \\
\stackrel{8}{8}\end{array}$ & 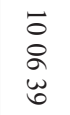 & 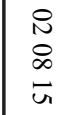 & 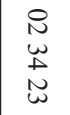 & 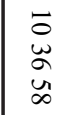 & 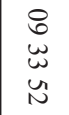 & $\begin{array}{l}0 \\
\text { U్ } \\
N \\
\sim \\
U\end{array}$ & $\begin{array}{l}\text { 을 } \\
\text { ป } \\
8\end{array}$ \\
\hline $\begin{array}{l}8 \\
8 \\
8 \\
9\end{array}$ & $\begin{array}{l}8 \\
8 \\
\square\end{array}$ & $\begin{array}{l}8 \\
8 \\
\infty \\
\frac{8}{6}\end{array}$ & $\begin{array}{l}8 \\
8 \\
8 \\
\text { 인 }\end{array}$ & $\begin{array}{l}8 \\
8 \\
8 \\
\text { 은 }\end{array}$ & 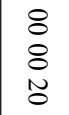 & $\begin{array}{l}8 \\
8 \\
N\end{array}$ & $\begin{array}{l}8 \\
8 \\
\circ\end{array}$ & $\begin{array}{l}8 \\
8 \\
0\end{array}$ & $\begin{array}{l}8 \\
8 \\
\tilde{0}\end{array}$ & $\begin{array}{l}8 \\
8 \\
\mathbb{N} \\
\end{array}$ & $\begin{array}{l}8 \\
8 \\
0\end{array}$ & $\begin{array}{l}8 \\
8 \\
0\end{array}$ \\
\hline
\end{tabular}


Tarikh Miladi Sepadan bagi Kenampakan Hilal Ramadan dalam Hadis Kurayb RA Berkaitan Mațla'

\begin{tabular}{|c|c|c|c|c|c|c|c|c|c|c|c|c|}
\hline $\begin{array}{l}8 \\
8 \\
8 \\
8\end{array}$ & $\begin{array}{l}\circ \\
n \\
8 \\
8\end{array}$ & $\begin{array}{l}n \\
\tilde{8} \\
8 \\
8\end{array}$ & $\begin{array}{l}9 \\
8 \\
8\end{array}$ & $\begin{array}{l}\infty \\
8 \\
8 \\
8\end{array}$ & $\begin{array}{l}n \\
m \\
0 \\
8\end{array}$ & 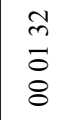 & $\begin{array}{l}0 \\
8 \\
8 \\
8\end{array}$ & $\begin{array}{l}0 \\
8 \\
8 \\
8\end{array}$ & $\begin{array}{l}m \\
8 \\
8 \\
8\end{array}$ & $\begin{array}{l}\overline{8} \\
8 \\
8\end{array}$ & $\begin{array}{l}\infty \\
8 \\
8 \\
8 \\
8\end{array}$ & $\begin{array}{l}1 \\
8 \\
8 \\
8\end{array}$ \\
\hline $\begin{array}{l}0 \\
\infty \\
\frac{1}{8}\end{array}$ & $\begin{array}{l}\infty \\
= \\
0 \\
=\end{array}$ & $\begin{array}{l}\infty \\
n \\
n \\
n\end{array}$ & $\begin{array}{l}n \\
0 \\
\sim \\
\infty \\
0\end{array}$ & $\begin{array}{l}\infty \\
m \\
\infty \\
\infty \\
0\end{array}$ & 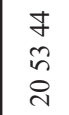 & 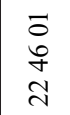 & $\begin{array}{l}\infty \\
\infty \\
\infty \\
\frac{\infty}{\delta}\end{array}$ & $\begin{array}{l}\text { q } \\
n \\
0 \\
0\end{array}$ & $\begin{array}{l}m \\
m \\
n \\
n\end{array}$ & $\begin{array}{l}\stackrel{9}{a} \\
m \\
\unlhd\end{array}$ & 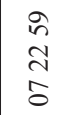 & $\begin{array}{l}0 \\
n \\
o \\
+ \\
8\end{array}$ \\
\hline $\begin{array}{l}\frac{1}{2} \\
\frac{m}{8}\end{array}$ & $\begin{array}{l}8 \\
0 \\
0 \\
2\end{array}$ & 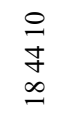 & $\begin{array}{l}1 \\
0 \\
0 \\
0\end{array}$ & 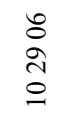 & 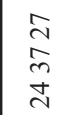 & 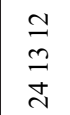 & 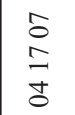 & 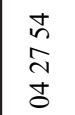 & $\begin{array}{l}\text { n } \\
n \\
\pm \\
\pm\end{array}$ & $\begin{array}{l}\infty \\
i n \\
\vdots \\
\Xi\end{array}$ & $\begin{array}{l}\frac{1}{0} \\
\stackrel{2}{0} \\
0\end{array}$ & $\begin{array}{l}\infty \\
N \\
\infty \\
0 \\
0\end{array}$ \\
\hline 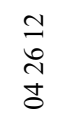 & $\begin{array}{l}\Xi \\
n \\
\pm\end{array}$ & $\begin{array}{l}\underset{q}{+} \\
0 \\
0 \\
-1\end{array}$ & $\begin{array}{l}\underset{\sim}{+} \\
\dot{\infty} \\
\dot{\infty} \\
\dot{0}\end{array}$ & 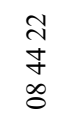 & 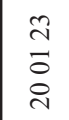 & $\begin{array}{l}\exists \\
\stackrel{J}{J} \\
\vec{N}\end{array}$ & 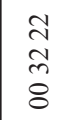 & $\frac{n}{n}$ & $\begin{array}{l}\Xi \\
\Xi \\
\beth\end{array}$ & $\begin{array}{l}\sim \\
\infty \\
\sim \\
\simeq\end{array}$ & $\begin{array}{l}\frac{n}{m} \\
\text { है }\end{array}$ & $\begin{array}{l}n \\
n \\
i n \\
0 \\
0\end{array}$ \\
\hline $\begin{array}{l}\overrightarrow{0} \\
\circ\end{array}$ & $\stackrel{n}{m}$ & $\begin{array}{l}\overrightarrow{0} \\
\dot{m}\end{array}$ & $\begin{array}{l}\overrightarrow{0} \\
\infty \\
-1\end{array}$ & $\stackrel{\text { I }}{\stackrel{2}{I}}$ & $\begin{array}{l}\tilde{I} \\
\text { Fे }\end{array}$ & $\begin{array}{l}\stackrel{D}{N} \\
F\end{array}$ & $\stackrel{m}{0}$ & $\begin{array}{l}\infty \\
\text { ஸn } \\
\&\end{array}$ & $\frac{m}{\sim}$ & $\begin{array}{l}\stackrel{\infty}{m} \\
\stackrel{\sim}{\sim}\end{array}$ & $\stackrel{\text { I }}{\text { I }}$ & $\stackrel{ }{\simeq}$ \\
\hline$\stackrel{\infty}{\stackrel{+}{\sigma}}$ & 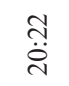 & $\stackrel{n}{\stackrel{n}{*}}$ & $\stackrel{\check{n}}{\check{\sigma}}$ & 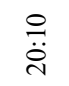 & 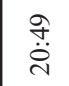 & $\begin{array}{l}\overrightarrow{\ddot{\lambda}} \\
\vec{\sim}\end{array}$ & $\begin{array}{l}8 \\
\dot{a}\end{array}$ & $\stackrel{\infty}{\dddot{\sigma}}$ & $\begin{array}{l}\infty \\
\stackrel{\leftrightarrow}{\dot{े}}\end{array}$ & 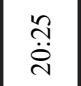 & $\stackrel{\overbrace{}}{\ddot{\Omega}}$ & 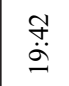 \\
\hline$\stackrel{0}{\dddot{a}}$ & $\begin{array}{l}\vec{n} \\
\ddot{\infty}\end{array}$ & $\stackrel{0}{\dddot{\sigma}}$ & 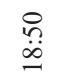 & $\frac{n}{a}$ & 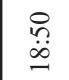 & $\frac{n}{\ddot{a}}$ & $\begin{array}{c}\stackrel{0}{+} \\
\dot{\infty}\end{array}$ & $\bar{\Xi}$ & 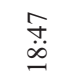 & $\stackrel{7}{\dddot{a}}$ & $\begin{array}{c}\vec{f} \\
\stackrel{\dot{\theta}}{\sigma}\end{array}$ & $\begin{array}{l}\hat{o} \\
\dot{a}\end{array}$ \\
\hline 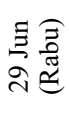 & 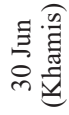 & 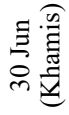 & 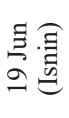 & 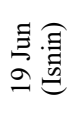 & 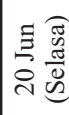 & 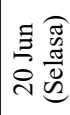 & 焉 & 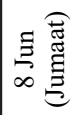 & 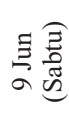 & 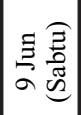 & 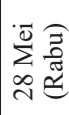 & 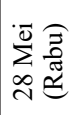 \\
\hline 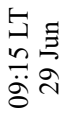 & & & 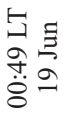 & 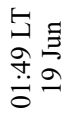 & & & 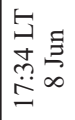 & 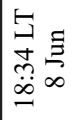 & & & 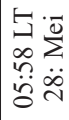 & 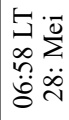 \\
\hline & & & 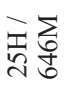 & & & & 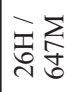 & & & & 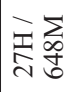 & \\
\hline 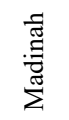 & 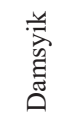 & 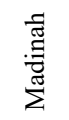 & 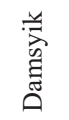 & 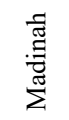 & 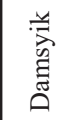 & 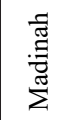 & 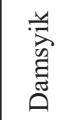 & 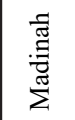 & 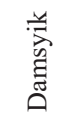 & $\begin{array}{l}\frac{\pi}{\pi} \\
\stackrel{\pi}{\pi} \\
\sum\end{array}$ & 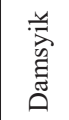 & 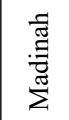 \\
\hline & & & $r$ & & & & $\infty$ & & & & $a$ & \\
\hline
\end{tabular}


Jurnal Fiqh, Vol. 18 No. 1 (2021) 67-102

\begin{tabular}{|c|c|c|c|c|c|c|c|c|c|c|c|c|}
\hline & & $\bar{N}$ & & & & $=$ & & & & $\vec{\sigma}$ & & \\
\hline 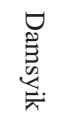 & 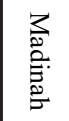 & 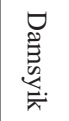 & 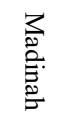 & 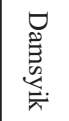 & 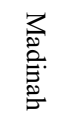 & 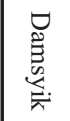 & \begin{tabular}{l}
3 \\
\multirow{2}{*}{} \\
है \\
है
\end{tabular} & 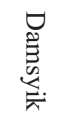 & 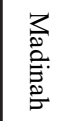 & 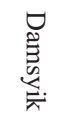 & 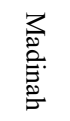 & 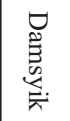 \\
\hline & & 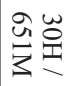 & & & & 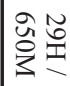 & & & & 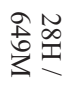 & & \\
\hline & 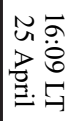 & 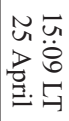 & & & 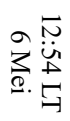 & 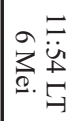 & & & 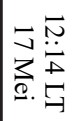 & 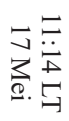 & & \\
\hline 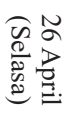 & 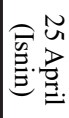 & 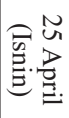 & 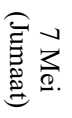 & 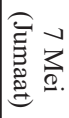 & 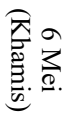 & 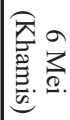 & 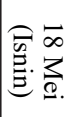 & 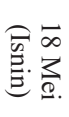 & 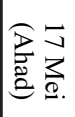 & 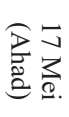 & 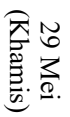 & 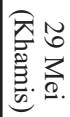 \\
\hline$\underset{\infty}{\stackrel{\infty}{\infty}}$ & $\underset{\stackrel{\infty}{\sim}}{\stackrel{\infty}{\sim}}$ & $\stackrel{\varpi \infty}{\grave{\Xi}}$ & $\begin{array}{l}\vec{\infty} \\
\underset{j}{\sim}\end{array}$ & $\begin{array}{l}\vec{\infty} \\
\dot{\tilde{\sigma}}\end{array}$ & $\begin{array}{l}\vec{\infty} \\
\ddot{v}\end{array}$ & $\begin{array}{l}\vec{\infty} \\
\dot{\sim}\end{array}$ & $\begin{array}{l}\overrightarrow{0} \\
\dot{\hat{\sigma}}\end{array}$ & $\begin{array}{l}\vec{\infty} \\
\dot{\perp} \\
\perp\end{array}$ & $\begin{array}{l}\overrightarrow{0} \\
\dot{\hat{N}}\end{array}$ & $\underset{\dot{\infty}}{\stackrel{\infty}{+}}$ & $\begin{array}{l}\overrightarrow{0} \\
\dot{\infty}\end{array}$ & $\begin{array}{l}\ddot{\infty} \\
\ddot{\oplus}\end{array}$ \\
\hline $\begin{array}{l}\vec{\oplus} \\
\stackrel{i}{0}\end{array}$ & $\begin{array}{l}\infty \\
\ddot{\infty} \\
\ddot{\sigma}\end{array}$ & $\begin{array}{l}\stackrel{\infty}{\dot{U}} \\
\dot{\mathcal{u}}\end{array}$ & $\begin{array}{l}\stackrel{\sim}{\circ} \\
\dot{\phi}\end{array}$ & $\begin{array}{l}\vec{\bullet} \\
\stackrel{\dot{\omega}}{\dot{\omega}}\end{array}$ & $\begin{array}{l}\stackrel{\vec{\sigma}}{\sigma} \\
\end{array}$ & $\begin{array}{l}\vec{\infty} \\
\dot{\leftrightarrow}\end{array}$ & $\begin{array}{l}\stackrel{\sim}{\circ} \\
\stackrel{\sigma}{\sigma}\end{array}$ & $\begin{array}{l}\vec{\sigma} \\
\ddot{\omega}\end{array}$ & 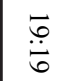 & $\begin{array}{l}\dot{\infty} \\
\ddot{\infty}\end{array}$ & $\begin{array}{l}\stackrel{\sim}{O} \\
\dot{H}\end{array}$ & $\begin{array}{l}\stackrel{\sim}{\dot{U}} \\
\stackrel{u}{u}\end{array}$ \\
\hline $\begin{array}{l}\text { N } \\
\text { D }\end{array}$ & $\begin{array}{l}\text { N } \\
\text { t }\end{array}$ & $\begin{array}{l}\stackrel{\infty}{\infty} \\
\infty\end{array}$ & 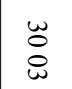 & $\begin{array}{l}\underset{\sim}{\omega} \\
\underset{N}{\omega}\end{array}$ & $\begin{array}{l}\stackrel{2}{2} \\
\stackrel{\omega}{6}\end{array}$ & 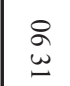 & $\begin{array}{l}\omega \\
0 \\
+\infty\end{array}$ & $\underset{\sim}{\frac{\omega}{\sigma}}$ & $\begin{array}{l}\stackrel{2}{\infty} \\
+\infty\end{array}$ & 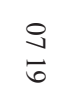 & $\begin{array}{l}\omega \\
\sigma \\
\sigma\end{array}$ & $\begin{array}{l}\tilde{\sigma} \\
\pm \\
\pm\end{array}$ \\
\hline $\begin{array}{l}= \\
N \\
\pm\end{array}$ & $\begin{array}{l}\dot{D} \\
\stackrel{ \pm}{ \pm} \\
\underset{\perp}{ }\end{array}$ & $\begin{array}{l}8 \\
= \\
\varnothing\end{array}$ & $\begin{array}{l}\Xi \\
w \\
\Xi \\
\Xi\end{array}$ & $\begin{array}{l}\vec{N} \\
\dot{w} \\
0\end{array}$ & $\begin{array}{l}8 \\
u \\
u \\
w\end{array}$ & $\begin{array}{l}\stackrel{0}{u} \\
\text { un } \\
\text { un }\end{array}$ & $\begin{array}{l}\vec{N} \\
\omega \\
0 \\
u \\
0\end{array}$ & $\begin{array}{l}\bar{N} \\
\Delta \\
N \\
\omega\end{array}$ & 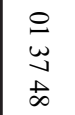 & $\begin{array}{l}\text { N } \\
\text { N } \\
\omega\end{array}$ & $\begin{array}{l}\vec{a} \\
\vec{t} \\
\dot{y}\end{array}$ & $\begin{array}{l}\vec{a} \\
\tilde{b} \\
+ \\
+\end{array}$ \\
\hline $\begin{array}{l}\bar{w} \\
0 \\
\tilde{N} \\
u \\
u\end{array}$ & 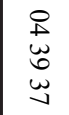 & $\begin{array}{l}\stackrel{Ð}{+} \\
\underset{N}{\omega} \\
0\end{array}$ & $\begin{array}{l}\omega \\
w \\
\omega \\
\&\end{array}$ & $\begin{array}{l}\vec{w} \\
+ \\
\overrightarrow{+} \\
u \\
u\end{array}$ & $\begin{array}{l}8 \\
\text { ur } \\
\text { ur } \\
8\end{array}$ & $\begin{array}{l}0 \\
u \\
0 \\
0 \\
0\end{array}$ & 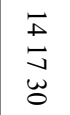 & $\begin{array}{l}\overrightarrow{+} \\
\underset{\omega}{\omega} \\
\vec{\infty}\end{array}$ & $\begin{array}{l}\text { O } \\
\vec{a} \\
\text { 品 }\end{array}$ & $\begin{array}{l}\text { or } \\
\sigma a \\
\text { ŭ }\end{array}$ & $\begin{array}{l}\vec{\infty} \\
\underset{N}{N} \\
\sim \\
\mathbb{D}\end{array}$ & $\begin{array}{l}\vec{\infty} \\
u \\
\sim \\
\sim\end{array}$ \\
\hline $\begin{array}{l}\vec{\omega} \\
\vec{a} \\
\bar{n}\end{array}$ & $\begin{array}{l}8 \\
\dot{\infty} \\
\infty \\
\infty \\
\infty\end{array}$ & $\begin{array}{l}0 \\
u \\
u \\
w \\
w\end{array}$ & 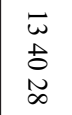 & $\begin{array}{l}u \\
w \\
u \\
u \\
u\end{array}$ & $\begin{array}{l}\stackrel{ }{N} \\
+ \\
+ \\
\infty\end{array}$ & $\begin{array}{l}\stackrel{D}{w} \\
\dot{D} \\
i\end{array}$ & $\begin{array}{l}\vec{\Delta} \\
\stackrel{\omega}{0} \\
\stackrel{+}{N}\end{array}$ & $\begin{array}{l}\vec{A} \\
\underset{N}{N} \\
\underset{\perp}{D}\end{array}$ & $\begin{array}{l}\stackrel{\infty}{ } \\
N \\
\infty \\
\omega\end{array}$ & 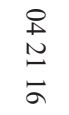 & $\begin{array}{l}\vec{\infty} \\
w \\
\vec{v} \\
t\end{array}$ & $\begin{array}{l}\vec{\infty} \\
8 \\
\dot{w} \\
w \\
u\end{array}$ \\
\hline 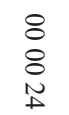 & $\begin{array}{l}8 \\
8 \\
8 \\
\dot{\omega}\end{array}$ & $\begin{array}{l}8 \\
8 \\
8 \\
0\end{array}$ & $\begin{array}{l}8 \\
8 \\
\text { N } \\
u\end{array}$ & $\begin{array}{l}8 \\
8 \\
\tilde{~} \\
\text { a }\end{array}$ & $\begin{array}{l}8 \\
8 \\
8 \\
8\end{array}$ & $\begin{array}{l}8 \\
8 \\
8 \\
\dot{\omega}\end{array}$ & $\begin{array}{l}8 \\
8 \\
\text { N }\end{array}$ & $\begin{array}{l}8 \\
8 \\
\& \\
w\end{array}$ & $\begin{array}{l}8 \\
8 \\
8 \\
8\end{array}$ & $\begin{array}{l}8 \\
8 \\
8 \\
8\end{array}$ & $\begin{array}{l}8 \\
8 \\
8 \\
\text { u }\end{array}$ & $\begin{array}{l}8 \\
8 \\
8 \\
\text { u' }\end{array}$ \\
\hline
\end{tabular}


Tarikh Miladi Sepadan bagi Kenampakan Hilal Ramadan dalam Hadis Kurayb RA Berkaitan Mațla'

\begin{tabular}{|c|c|c|c|c|c|c|c|c|c|c|c|c|}
\hline \begin{tabular}{l}
\multirow{2}{*}{} \\
8 \\
8 \\
8
\end{tabular} & $\begin{array}{l}m \\
8 \\
8 \\
8\end{array}$ & $\begin{array}{l}1 \\
8 \\
8 \\
8\end{array}$ & $\begin{array}{l}8 \\
5 \\
8\end{array}$ & $\begin{array}{l}\infty \\
0 \\
0 \\
8\end{array}$ & $\begin{array}{l}1 \\
8 \\
8 \\
8\end{array}$ & $\begin{array}{l}8 \\
8 \\
8 \\
8\end{array}$ & $\begin{array}{l}\text { ㄹ } \\
8 \\
8 \\
8\end{array}$ & $\begin{array}{l}\vec{n} \\
8 \\
8\end{array}$ & $\begin{array}{l}4 \\
8 \\
8 \\
8\end{array}$ & $\begin{array}{l}+ \\
0 \\
8 \\
8\end{array}$ & $\begin{array}{l}\vec{n} \\
8 \\
8\end{array}$ & $\begin{array}{l}8 \\
8 \\
8 \\
8\end{array}$ \\
\hline $\begin{array}{l}\stackrel{n}{n} \\
\sim \\
\simeq\end{array}$ & $\begin{array}{l}\hat{\imath} \\
\bar{a}\end{array}$ & $\begin{array}{l}\vec{m} \\
m \\
\infty \\
\infty\end{array}$ & $\begin{array}{l}\mathfrak{f} \\
\stackrel{+}{q} \\
\vec{v}\end{array}$ & $\begin{array}{l}\stackrel{+}{n} \\
\stackrel{+}{+} \\
\vec{\sim}\end{array}$ & 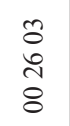 & 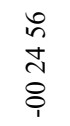 & 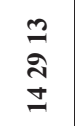 & $\begin{array}{l}n \\
m \\
n \\
\pm \\
=\end{array}$ & 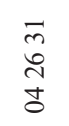 & 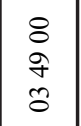 & $\begin{array}{l}8 \\
\stackrel{\infty}{=}\end{array}$ & $\begin{array}{l}\infty \\
\cdots \\
0 \\
\infty\end{array}$ \\
\hline $\begin{array}{l}n \\
\sim \\
\sim \\
\simeq\end{array}$ & $\begin{array}{l}n \\
\tilde{a} \\
8 \\
8\end{array}$ & 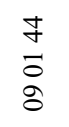 & $\begin{array}{l}\sim \\
\sim \\
\vec{\sim}\end{array}$ & $\begin{array}{l}\hat{0} \\
\text { ㄱ } \\
\bar{\lambda}\end{array}$ & $\begin{array}{l}a \\
i \\
n \\
\infty\end{array}$ & $\begin{array}{l}n \\
n \\
0 \\
\vdots\end{array}$ & $\begin{array}{l} \pm \\
\Xi \\
\Xi\end{array}$ & $\begin{array}{l}n \\
\tilde{0} \\
\pm \\
\pm\end{array}$ & $\begin{array}{l}\text { o } \\
\text { à } \\
\text { à }\end{array}$ & $\begin{array}{l}\infty \\
\stackrel{\infty}{+} \\
\infty \\
i \\
\dot{0}\end{array}$ & 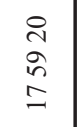 & $\begin{array}{l}n \\
\therefore \\
n \\
n\end{array}$ \\
\hline 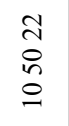 & $\frac{\infty}{n}$ & $\begin{array}{l}n \\
0 \\
m \\
\vdots \\
0\end{array}$ & 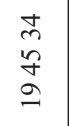 & \begin{tabular}{l}
\multirow{f}{*}{} \\
$\stackrel{m}{-}$
\end{tabular} & $\begin{array}{l}\infty \\
n \\
n \\
0 \\
1\end{array}$ & $\begin{array}{l}N \\
\tilde{N} \\
\infty \\
0 \\
i\end{array}$ & $\begin{array}{l}\stackrel{8}{n} \\
\stackrel{e}{2} \\
\end{array}$ & 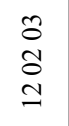 & $\begin{array}{l}\text { o } \\
\text { లે } \\
\text { } \\
0\end{array}$ & 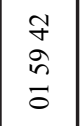 & $\begin{array}{l}\frac{a}{6} \\
6 \\
6\end{array}$ & $\begin{array}{l}\dot{m} \\
\stackrel{n}{n} \\
n\end{array}$ \\
\hline $\begin{array}{l}\text { f } \\
\stackrel{\sim}{\sim}\end{array}$ & $\begin{array}{l}\stackrel{\infty}{+} \\
0\end{array}$ & 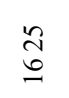 & $\begin{array}{l}\stackrel{\infty}{+} \\
\stackrel{+}{+}\end{array}$ & \begin{tabular}{l}
23 \\
\multirow{a}{a}{} \\
\end{tabular} & $\begin{array}{l}n \\
0 \\
0\end{array}$ & $\begin{array}{l}8 \\
8 \\
8\end{array}$ & $\begin{array}{l}8 \\
\ddot{1}\end{array}$ & $\begin{array}{l}\text { f } \\
\text { ป̀ }\end{array}$ & $\begin{array}{l}\text { ते } \\
\infty \\
\infty\end{array}$ & $\begin{array}{l} \pm \\
0 \\
\infty\end{array}$ & $\begin{array}{l}\text { ते } \\
\text { }\end{array}$ & $\begin{array}{l}\text { d } \\
\text { m }\end{array}$ \\
\hline$\stackrel{\leftrightarrow}{\stackrel{\leftrightarrow}{\sigma}}$ & $\begin{array}{l}\infty \\
\infty \\
\infty \\
\infty\end{array}$ & $\stackrel{\infty}{\stackrel{N}{ٍ}}$ & $\begin{array}{l}\dot{0} \\
\dot{\leftrightarrow}\end{array}$ & $\vec{\overbrace{}}$ & $\begin{array}{l}\dot{D} \\
\dot{\infty}\end{array}$ & $\begin{array}{l}\vec{f} \\
\dot{\infty}\end{array}$ & $\stackrel{\square}{\dddot{\theta}}$ & $\begin{array}{l}\stackrel{a}{a} \\
\stackrel{a}{-}\end{array}$ & $\stackrel{ }{\ddot{\infty}}$ & $\begin{array}{l}n \\
\infty \\
\infty\end{array}$ & $\stackrel{\infty}{\stackrel{N}{ٍ}}$ & $\begin{array}{l}\text { Oे } \\
\dot{\leftrightarrow}\end{array}$ \\
\hline $\begin{array}{l}\tilde{n} \\
\infty \\
\infty\end{array}$ & $\begin{array}{l}\stackrel{0}{\dddot{0}} \\
\stackrel{\infty}{-}\end{array}$ & 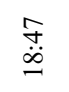 & $\underset{\not ̈}{\not}$ & $\stackrel{\infty}{\stackrel{\infty}{\infty}}$ & \begin{tabular}{l}
\multirow{O}{0}{} \\
$\dot{\infty}$ \\
-
\end{tabular} & $\stackrel{\mathscr{f}}{\ddot{\infty}}$ & $\stackrel{\mathscr{\theta}}{\ddot{\theta}}$ & $\begin{array}{c}\underset{+}{\forall} \\
\stackrel{0}{-}\end{array}$ & $\stackrel{n}{n}$ & $\begin{array}{l}\grave{m} \\
\dot{\infty}\end{array}$ & 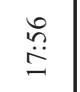 & $\begin{array}{l}\stackrel{\leftrightarrow}{+} \\
\stackrel{\infty}{-}\end{array}$ \\
\hline 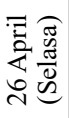 & 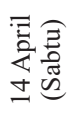 & 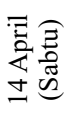 & 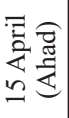 & 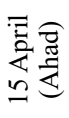 & 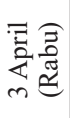 & 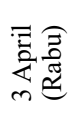 & 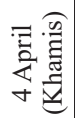 & 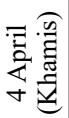 & 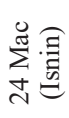 & 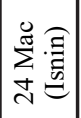 & 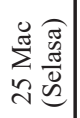 & 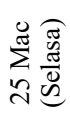 \\
\hline & 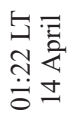 & 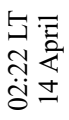 & & & 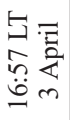 & 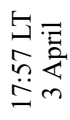 & & & 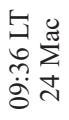 & 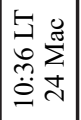 & & \\
\hline & 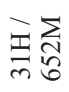 & & & & 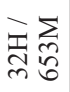 & & & & 焉考 & & & \\
\hline$\stackrel{\vec{\pi}}{\stackrel{\Xi}{\exists}}$ & 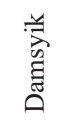 & 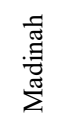 & 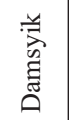 & 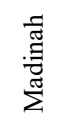 & 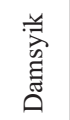 & $\begin{array}{l}\text { 卺 } \\
\text { 营 }\end{array}$ & 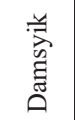 & 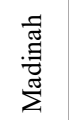 & 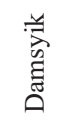 & 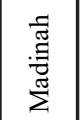 & 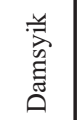 & 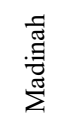 \\
\hline & $\underline{2}$ & & & & \pm & & & & $\cong$ & & & \\
\hline
\end{tabular}


Jurnal Fiqh, Vol. 18 No. 1 (2021) 67-102

\begin{tabular}{|c|c|c|c|c|c|c|c|c|c|c|c|c|}
\hline$\sigma$ & & & & $\vec{\infty}$ & & & & $\Xi$ & & & & $\sigma$ \\
\hline 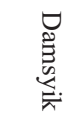 & $\begin{array}{l}3 \\
\text { : } \\
\text { : } \\
\text { : }\end{array}$ & 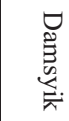 & 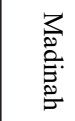 & 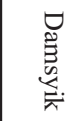 & 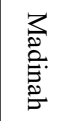 & 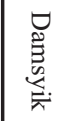 & \begin{tabular}{l}
3 \\
\multirow{2}{*}{} \\
: \\
है
\end{tabular} & 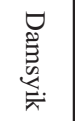 & 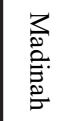 & 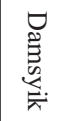 & 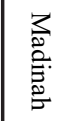 & 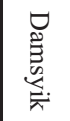 \\
\hline $\begin{array}{l}\hat{\omega} \omega \\
\text { w } \\
\underline{3}\end{array}$ & & & & $\begin{array}{l}\dot{u} \\
\vec{y} \\
\overrightarrow{3}\end{array}$ & & & & 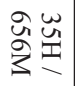 & & & & 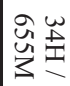 \\
\hline $\begin{array}{ll}\infty & 8 \\
1 & \stackrel{9}{10} \\
8 & 0 \\
0 & =\end{array}$ & & & 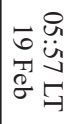 & 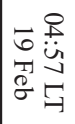 & & & 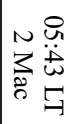 & 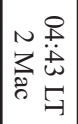 & & & 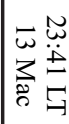 & 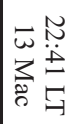 \\
\hline 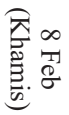 & 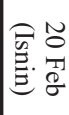 & 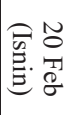 & 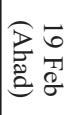 & 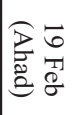 & 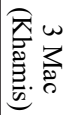 & 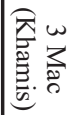 & 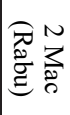 & 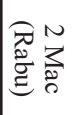 & 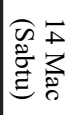 & 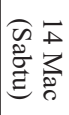 & 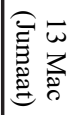 & 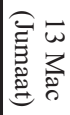 \\
\hline$\underset{\sim}{\vec{N}}$ & 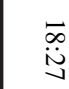 & $\vec{i}$ & $\begin{array}{l}\varpi \\
\ddot{\tilde{\sigma}}\end{array}$ & $\underset{\ddot{\omega}}{\vec{\omega}}$ & 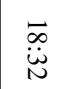 & $\begin{array}{l}\vec{\oplus} \\
\ddot{\oplus}\end{array}$ & $\underset{\dot{\infty}}{\stackrel{\infty}{\omega}}$ & $\begin{array}{l}\overrightarrow{\ddot{\theta}} \\
\ddot{\theta}\end{array}$ & $\begin{array}{l}\vec{\infty} \\
\dot{\omega}\end{array}$ & $\underset{\vec{\infty}}{\vec{\infty}}$ & $\begin{array}{l}\vec{\infty} \\
\dot{u}\end{array}$ & $\underset{\dot{\infty}}{\vec{\phi}}$ \\
\hline$\underset{\ddot{\Delta}}{\ddot{\Delta}}$ & $\underset{\dot{\infty}}{\vec{\infty}}$ & $\begin{array}{l}\overrightarrow{0} \\
\dot{\leftrightarrow}\end{array}$ & $\begin{array}{l}\ddot{\infty} \\
\ddot{\infty}\end{array}$ & $\underset{\ddot{v}}{ت}$ & $\begin{array}{l}\varpi \\
\stackrel{\Delta}{*}\end{array}$ & $\begin{array}{l}\vec{\varphi} \\
\stackrel{\dot{\omega}}{ }\end{array}$ & $\begin{array}{l}\vec{\infty} \\
\underset{u}{u}\end{array}$ & $\begin{array}{l}\infty \\
\dot{\theta}\end{array}$ & 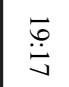 & $\begin{array}{l}\infty \\
\dot{u} \\
\dot{u}\end{array}$ & $\underset{\dot{\sigma}}{\stackrel{\infty}{\sigma}}$ & $\underset{\dot{\omega}}{\vec{\omega}}$ \\
\hline$\stackrel{\Xi}{\mathrm{\omega}}$ & $\begin{array}{l}\tilde{a}^{\prime} \\
\underline{o}\end{array}$ & $\begin{array}{l}\omega_{\omega} \\
w \\
u\end{array}$ & $\begin{array}{l}\bar{N} \\
\text { N }\end{array}$ & $\begin{array}{l}\vec{N} \\
\underset{\perp}{\Delta}\end{array}$ & $\begin{array}{l}\text { a } \\
\hat{b}\end{array}$ & $\begin{array}{l}\tilde{a}_{\infty} \\
\tilde{\omega}_{1}\end{array}$ & $\begin{array}{l}\vec{N} \\
+\infty\end{array}$ & $\begin{array}{l}\bar{N} \\
\text { un }\end{array}$ & $\begin{array}{l}\vec{\infty} \\
\text { un } \\
u_{n}\end{array}$ & $\begin{array}{l}\overrightarrow{0} \\
0 \\
0\end{array}$ & $\begin{array}{l}\dot{1} \\
\text { On } \\
8\end{array}$ & $\begin{array}{l}\dot{D} \\
\stackrel{1}{L_{1}}\end{array}$ \\
\hline $\begin{array}{l}8 \\
N \\
+ \\
N \\
\infty\end{array}$ & $\begin{array}{l}\vec{\omega} \\
\stackrel{+}{\infty} \\
\vec{\perp}\end{array}$ & 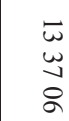 & $\begin{array}{l}0 \\
w \\
w \\
u \\
u\end{array}$ & $\begin{array}{l}\dot{\omega} \\
\bar{u} \\
\tilde{\omega}\end{array}$ & $\begin{array}{l}\vec{D} \\
\vec{L} \\
\vec{u} \\
\text { हn }\end{array}$ & 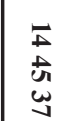 & 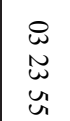 & $\begin{array}{l}\dot{\omega} \\
+ \\
\stackrel{+}{\omega}\end{array}$ & 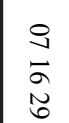 & $\begin{array}{l}0 \\
\omega \\
\omega \\
0 \\
u \\
0\end{array}$ & & \\
\hline $\begin{array}{l}\stackrel{D}{1} \\
\text { N } \\
N\end{array}$ & $\begin{array}{l}\vec{u} \\
\text { N } \\
\text { un }\end{array}$ & $\begin{array}{l}\bar{u} \\
w \\
\alpha \\
u \\
u\end{array}$ & $\begin{array}{l}\stackrel{8}{+} \\
\breve{\alpha} \\
\omega \\
\omega\end{array}$ & $\begin{array}{c}0 \\
+ \\
\text { y } \\
0 \\
0\end{array}$ & $\begin{array}{l}\vec{a} \\
\dot{\omega} \\
\dot{\omega} \\
\underline{\omega}\end{array}$ & $\underset{\infty}{\underset{\omega}{u}}$ & $\begin{array}{l}0 \\
u \\
\tilde{D} \\
0 \\
\$\end{array}$ & 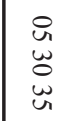 & 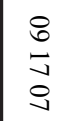 & $\begin{array}{l}8 \\
\text { N } \\
\text { O } \\
\text { N }\end{array}$ & & \\
\hline $\begin{array}{l}\stackrel{1}{1} \\
w \\
0 \\
N \\
N\end{array}$ & 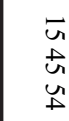 & $\begin{array}{l}\bar{u} \\
w \\
u \\
w \\
w\end{array}$ & $\begin{array}{l}\stackrel{8}{+} \\
u \\
\frac{1}{0}\end{array}$ & 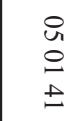 & $\begin{array}{l}\vec{a} \\
\vec{A} \\
\stackrel{v}{J}\end{array}$ & $\begin{array}{l}\vec{a} \\
\underset{\omega}{\sim} \\
\mathbb{a}\end{array}$ & $\begin{array}{l}O \\
u \\
N \\
+\end{array}$ & $\begin{array}{l}\text { o } \\
\omega \\
\omega \\
0\end{array}$ & 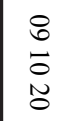 & $\begin{array}{l}8 \\
\omega \\
\omega \\
\bar{N}\end{array}$ & & \\
\hline $\begin{array}{l}8 \\
8 \\
8 \\
0 \\
0\end{array}$ & $\begin{array}{l}8 \\
8 \\
\dot{\omega}\end{array}$ & $\begin{array}{l}8 \\
8 \\
\stackrel{5}{w} \\
+\end{array}$ & $\begin{array}{l}8 \\
8 \\
8 \\
0\end{array}$ & $\begin{array}{l}8 \\
8 \\
8 \\
0\end{array}$ & $\begin{array}{l}8 \\
8 \\
\underset{b}{0}\end{array}$ & 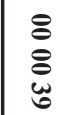 & $\begin{array}{l}8 \\
8 \\
8 \\
1\end{array}$ & $\begin{array}{l}8 \\
8 \\
8 \\
8\end{array}$ & $\begin{array}{l}8 \\
8 \\
\grave{\omega}\end{array}$ & $\begin{array}{l}8 \\
8 \\
\text { ๘ }\end{array}$ & & \\
\hline
\end{tabular}




\begin{tabular}{|c|c|c|c|c|c|c|c|c|c|c|c|c|}
\hline $\begin{array}{l}3 \\
8 \\
8 \\
8\end{array}$ & $\begin{array}{l}n \\
m \\
8 \\
8 \\
8\end{array}$ & $\begin{array}{l}n \\
\tilde{8} \\
8 \\
8\end{array}$ & $\begin{array}{l}8 \\
8 \\
8\end{array}$ & $\begin{array}{l}8 \\
8 \\
8 \\
8\end{array}$ & $\begin{array}{l}\hat{i} \\
\tilde{8} \\
8 \\
8\end{array}$ & $\begin{array}{l}\hat{1} \\
8 \\
8 \\
8\end{array}$ & $\begin{array}{l}1 \\
8 \\
8 \\
8 \\
8\end{array}$ & $\begin{array}{l}1 \\
8 \\
8 \\
8\end{array}$ & $\begin{array}{l}n \\
8 \\
0 \\
8\end{array}$ & $\begin{array}{l}n \\
0 \\
0 \\
8\end{array}$ & & \\
\hline 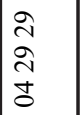 & $\begin{array}{l}\dot{m} \\
\vec{n} \\
n\end{array}$ & $\begin{array}{l}i n \\
n n \\
n \\
n\end{array}$ & $\begin{array}{l}\tilde{N} \\
\infty \\
\infty \\
8\end{array}$ & $\begin{array}{l}0 \\
n \\
0 \\
n \\
8 \\
8\end{array}$ & $\begin{array}{l}\stackrel{0}{ } \\
\text { I } \\
\text { Jे } \\
\text { ב }\end{array}$ & 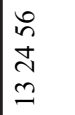 & $\begin{array}{l}8 \\
8 \\
9 \\
2\end{array}$ & $\begin{array}{l}0 \\
0 \\
0 \\
0\end{array}$ & $\begin{array}{l}0 \\
2 \\
i n \\
\infty \\
\infty\end{array}$ & $\begin{array}{l}8 \\
\qquad \\
8 \\
8 \\
\text { in }\end{array}$ & & \\
\hline 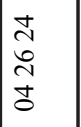 & $\begin{array}{l}n \\
\infty \\
\infty \\
n \\
n\end{array}$ & 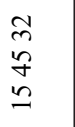 & 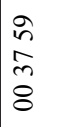 & $\begin{array}{l}\stackrel{m}{\sigma} \\
\vec{\gamma} \\
\delta\end{array}$ & 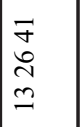 & 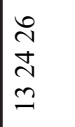 & $\begin{array}{l}\text { N } \\
\infty \\
\text { N } \\
\varnothing \\
0\end{array}$ & 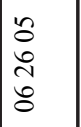 & $\begin{array}{l}0 \\
\text { ì } \\
\stackrel{\text { N }}{1}\end{array}$ & $\begin{array}{l}\text { N } \\
\text { N } \\
\text { ָे }\end{array}$ & & \\
\hline $\begin{array}{l}0 \\
i \\
o \\
+ \\
0 \\
\delta\end{array}$ & $\begin{array}{l}\tilde{r} \\
\tilde{\sim} \\
\tilde{\sigma}\end{array}$ & $\begin{array}{l}\infty \\
\stackrel{+}{+} \\
\stackrel{1}{n} \\
m \\
=\end{array}$ & $\begin{array}{l}n \\
m \\
n \\
0 \\
0 \\
1\end{array}$ & $\begin{array}{l}\vec{N} \\
\infty \\
0 \\
0 \\
1\end{array}$ & \begin{tabular}{l}
$\mathcal{Y}$ \\
$\stackrel{9}{9}$ \\
$\stackrel{9}{9}$ \\
\hdashline
\end{tabular} & $\begin{array}{l}\hat{N} \\
\vec{N} \\
=\end{array}$ & $\begin{array}{l}n \\
\tilde{n} \\
\tilde{y} \\
\tilde{\sigma}\end{array}$ & $\begin{array}{l}0 \\
0 \\
0 \\
0 \\
0\end{array}$ & $\begin{array}{l}n \\
0 \\
0 \\
0\end{array}$ & $\begin{array}{l}\tilde{r} \\
\sim \\
\tilde{n} \\
=\end{array}$ & & \\
\hline $\begin{array}{l}\sigma \\
=\end{array}$ & $\begin{array}{l}\Xi \\
0 \\
m\end{array}$ & $\begin{array}{l}\sigma \\
i \\
m\end{array}$ & \begin{tabular}{l}
\multirow{2}{*}{} \\
ș
\end{tabular} & $\begin{array}{l}\text { f } \\
\text { ح̂ }\end{array}$ & $\begin{array}{l}\text { f } \\
\text { L }\end{array}$ & $\begin{array}{l}\text { 交 } \\
\stackrel{\sim}{\sim}\end{array}$ & ì & $\begin{array}{l}m \\
\sim \\
\sim\end{array}$ & 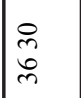 & $\begin{array}{l}\tilde{J} \\
\tilde{n} \\
\tilde{n}\end{array}$ & $\begin{array}{l}\hat{n} \\
\hat{p} \\
\hat{\varphi}\end{array}$ & $\begin{array}{c}\bar{m} \\
\hat{p}\end{array}$ \\
\hline $\begin{array}{l}\underset{\sim}{\sigma} \\
\dot{\infty}\end{array}$ & 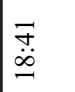 & 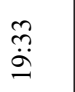 & $\stackrel{n}{\dddot{\pi}}$ & $\begin{array}{l}0 \\
\ddot{0} \\
-0 \\
\end{array}$ & $\underset{\ddot{\alpha}}{\stackrel{\partial}{\sigma}}$ & $\frac{0}{\ddot{a}}$ & 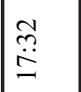 & $\begin{array}{l}0 \\
\dddot{n} \\
\infty \\
0\end{array}$ & $\begin{array}{l}\stackrel{g}{\dddot{\infty}} \\
\dot{\infty}\end{array}$ & 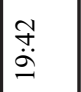 & 点 & 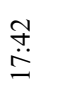 \\
\hline $\begin{array}{l}\stackrel{\leftrightarrow}{\oplus} \\
\dot{\infty} \\
-\end{array}$ & $\stackrel{\overbrace{}}{\stackrel{\overbrace{}}{I}}$ & $\overrightarrow{\tilde{\infty}}$ & $\stackrel{\sim}{\dddot{I}}$ & $\stackrel{m}{\dddot{\infty}}$ & $\stackrel{m}{\dddot{I}}$ & $\underset{\ddot{\infty}}{\ddot{\alpha}}$ & 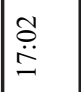 & $\begin{array}{l}\stackrel{0}{0} \\
\dot{\infty}\end{array}$ & $\stackrel{\overbrace{}}{\stackrel{\Xi}{I}}$ & $\begin{array}{l}\hat{o} \\
\dot{\phi} \\
-\end{array}$ & 華 & $\begin{array}{l}\infty \\
\stackrel{\infty}{\Xi} \\
=\end{array}$ \\
\hline 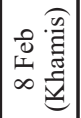 & 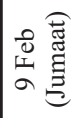 & 远 & $\begin{array}{l}\text { : } \\
\stackrel{\Xi}{0} \\
\infty \\
\sim\end{array}$ & 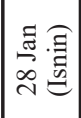 & 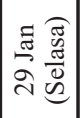 & 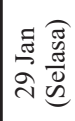 & 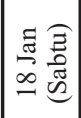 & 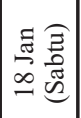 & 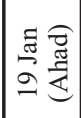 & 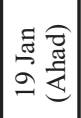 & 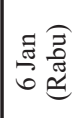 & 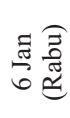 \\
\hline 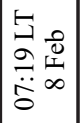 & & & 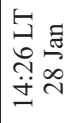 & 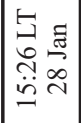 & & & 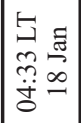 & 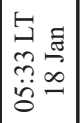 & & & 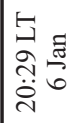 & 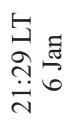 \\
\hline & & & $\begin{array}{l}\sum \\
0 \\
6 \\
0 \\
7 \\
\infty \\
n \\
n\end{array}$ & & & & 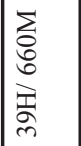 & & & & 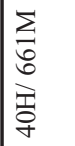 & \\
\hline 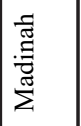 & 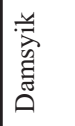 & 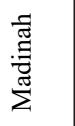 & 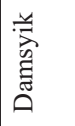 & 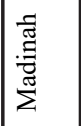 & 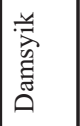 & 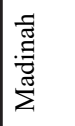 & 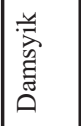 & 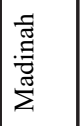 & 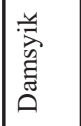 & 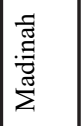 & 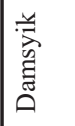 & 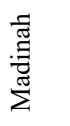 \\
\hline & & & $\stackrel{\sim}{ }$ & & & & $\bar{\sim}$ & & & & ส & \\
\hline
\end{tabular}




\begin{tabular}{|c|c|c|c|c|c|c|c|c|c|c|c|}
\hline & $\tilde{u}$ & & & & $\stackrel{\sim}{\perp}$ & & & & $\tilde{\omega}$ & & \\
\hline 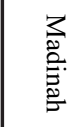 & 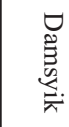 & 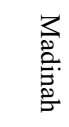 & 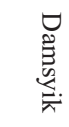 & 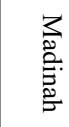 & 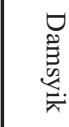 & 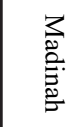 & 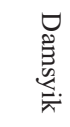 & 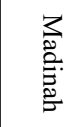 & 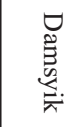 & 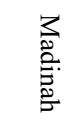 & 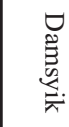 \\
\hline & 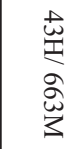 & & & & 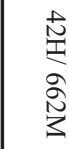 & & & & 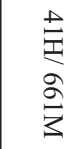 & & \\
\hline & ur & & & $\vec{a} \overrightarrow{\vec{q}}$ & 可 & & & 芦 & 胥 & & \\
\hline 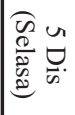 & 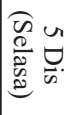 & 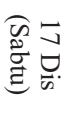 & 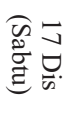 & 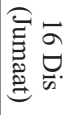 & 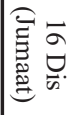 & 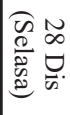 & 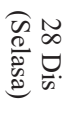 & 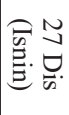 & 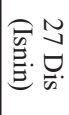 & 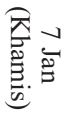 & 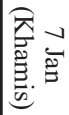 \\
\hline$\stackrel{\vec{\oplus}}{\ddot{\oplus}}$ & $\overline{\dot{u}}$ & $\begin{array}{l}\vec{\Delta} \\
\ddot{\Delta}\end{array}$ & $\overrightarrow{\dot{i}}$ & $\underset{\ddot{\Delta}}{\vec{\Delta}}$ & $\overline{\stackrel{i}{u}}$ & $\overrightarrow{\mathrm{i}}$ & $\begin{array}{l}\overrightarrow{\grave{\Delta}} \\
\text {. }\end{array}$ & $\overrightarrow{\ddot{v}}$ & $\overrightarrow{\overline{\dot{ }}}$ & $\overrightarrow{\vec{j}}$ & $\overline{\stackrel{\vec{w}}{\omega}}$ \\
\hline$\vec{i}$ & $\overline{\dot{\vec{d}}}$ & $\begin{array}{l}\dot{\infty} \\
\dot{U}\end{array}$ & $\underset{\infty}{\vec{\infty}}$ & $\overrightarrow{\mathrm{i}}$ & $\overrightarrow{\stackrel{\vec{v}}{u}}$ & $\begin{array}{l}\vec{\sigma} \\
\stackrel{\omega}{0}\end{array}$ & $\underset{\vec{u}}{\vec{u}}$ & $\stackrel{\infty}{\ominus}$ & $\underset{\mathrm{i}}{\stackrel{\overrightarrow{\mathrm{d}}}{ }}$ & $\begin{array}{l}\vec{\infty} \\
\stackrel{t}{0}\end{array}$ & $\underset{\ddot{\omega}}{\vec{\Delta}}$ \\
\hline $\begin{array}{l}8 \\
\pm\end{array}$ & $\begin{array}{l}8 \\
8\end{array}$ & $\begin{array}{l}n \\
\pm \\
U\end{array}$ & $\begin{array}{l}\tilde{N} \\
\vec{A}\end{array}$ & $\begin{array}{l}8 \\
\text { un }\end{array}$ & $\begin{array}{l}8 \\
\pm \\
+\end{array}$ & $\underset{\vec{\infty}}{\stackrel{\omega}{\sigma}}$ & $\begin{array}{l}\stackrel{\omega}{\Xi} \\
=\end{array}$ & $\stackrel{g}{\exists}$ & $\begin{array}{c}\stackrel{ }{3} \\
0\end{array}$ & $\begin{array}{l}\tilde{O} \\
N \\
N\end{array}$ & $\begin{array}{l}\tilde{N} \\
\tilde{N} \\
\stackrel{A}{n}\end{array}$ \\
\hline $\begin{array}{l}\dot{b} \\
w \\
0 \\
w \\
w\end{array}$ & $\begin{array}{l}\dot{1} \\
\dot{1} \\
0 \\
\tilde{u} \\
u\end{array}$ & $\begin{array}{l}\stackrel{\Omega}{ } \\
w \\
w \\
\text { an }\end{array}$ & $\begin{array}{l}8 \\
u \\
u \\
a \\
a\end{array}$ & $\begin{array}{l}\dot{d} \\
\tilde{N} \\
\tilde{N}\end{array}$ & $\begin{array}{l}\dot{b} \\
\omega \\
\omega \\
\vec{t}\end{array}$ & $\begin{array}{l}= \\
\vec{t} \\
w \\
w\end{array}$ & $\begin{array}{l}0 \\
0 \\
\text { N } \\
\pm\end{array}$ & $\begin{array}{l}8 \\
\stackrel{8}{+} \\
w \\
0\end{array}$ & $\begin{array}{l}\dot{8} \\
\vec{\sigma} \\
w \\
+\end{array}$ & $\begin{array}{l}\infty \\
\infty \\
\infty \\
\infty\end{array}$ & 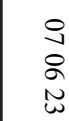 \\
\hline $\begin{array}{l}\text { O } \\
\text { O } \\
\text { O }\end{array}$ & $\begin{array}{l}\dot{\omega} \\
0 \\
0 \\
0\end{array}$ & $\begin{array}{l}= \\
\omega \\
\stackrel{\omega}{\omega}\end{array}$ & $\begin{array}{l}\bar{N} \\
\varnothing \\
\infty \\
u\end{array}$ & 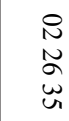 & 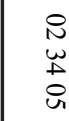 & $\begin{array}{l}\sigma \\
\bar{\omega} \\
\omega \\
u\end{array}$ & $\begin{array}{l}\vec{\sigma} \\
\bar{u} \\
u \\
\sigma\end{array}$ & $\begin{array}{l}\stackrel{0}{\omega} \\
\omega \\
\omega \\
0\end{array}$ & $\begin{array}{l}\stackrel{D}{\omega} \\
\text { N } \\
\tilde{\omega}\end{array}$ & $\begin{array}{l}= \\
\bar{N} \\
\text { U্口 }\end{array}$ & $\begin{array}{l}= \\
\bar{u} \\
\vec{\sigma}\end{array}$ \\
\hline $\begin{array}{l}1 \\
0 \\
\infty \\
\infty \\
\Delta\end{array}$ & $\begin{array}{l}\dot{1} \\
\text { N } \\
\text { 足 } \\
\text { a }\end{array}$ & $\begin{array}{l}\triangleright \\
\infty \\
\vec{\omega} \\
+\end{array}$ & 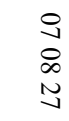 & $\begin{array}{l}\dot{0} \\
\text { D } \\
\text { Un }\end{array}$ & $\begin{array}{l}\dot{b} \\
u \\
\omega \\
\dot{\omega}\end{array}$ & $\begin{array}{l}\vec{\nexists} \\
\infty \\
\ddot{b}\end{array}$ & $\begin{array}{l}\bar{N} \\
w \\
u \\
0\end{array}$ & $\begin{array}{l}\text { O } \\
\text { N } \\
+ \\
+\end{array}$ & $\begin{array}{l}\stackrel{0}{N} \\
\stackrel{+}{W} \\
\stackrel{0}{0}\end{array}$ & $\begin{array}{l}\overrightarrow{0} \\
\vec{\infty} \\
\vec{a}\end{array}$ & $\begin{array}{l}8 \\
\frac{B}{ \pm} \\
\frac{N}{N}\end{array}$ \\
\hline $\begin{array}{l}8 \\
8 \\
8 \\
0\end{array}$ & $\begin{array}{l}8 \\
8 \\
\circ\end{array}$ & $\begin{array}{l}8 \\
8 \\
6\end{array}$ & $\begin{array}{l}8 \\
8 \\
6\end{array}$ & $\begin{array}{l}8 \\
8 \\
0 \\
0\end{array}$ & $\begin{array}{l}8 \\
8 \\
0\end{array}$ & $\begin{array}{l}8 \\
8 \\
0\end{array}$ & $\begin{array}{l}8 \\
8 \\
8 \\
5\end{array}$ & $\begin{array}{l}8 \\
8 \\
8 \\
0 \\
0\end{array}$ & $\begin{array}{l}8 \\
8 \\
8 \\
0\end{array}$ & $\begin{array}{l}8 \\
8 \\
0 \\
0\end{array}$ & $\begin{array}{l}8 \\
8 \\
\stackrel{0}{0}\end{array}$ \\
\hline
\end{tabular}


Tarikh Miladi Sepadan bagi Kenampakan Hilal Ramadan dalam Hadis Kurayb RA Berkaitan Mațla'

\begin{tabular}{|c|c|c|c|c|c|c|c|c|c|}
\hline $\begin{array}{l}\text { 응 } \\
8 \\
8\end{array}$ & $\begin{array}{l}1 \\
8 \\
8\end{array}$ & $\begin{array}{l}\text { O } \\
8 \\
8 \\
8\end{array}$ & $\begin{array}{l}1 \\
\delta \\
8 \\
8\end{array}$ & $\begin{array}{l}\frac{9}{8} \\
8 \\
8\end{array}$ & $\begin{array}{l}9 \\
8 \\
8\end{array}$ & & & $\begin{array}{l}n \\
8 \\
8\end{array}$ & $\begin{array}{l} \pm \\
8 \\
8\end{array}$ \\
\hline 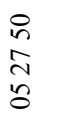 & $\begin{array}{l}= \\
0 \\
0\end{array}$ & 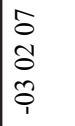 & 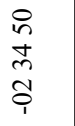 & $\begin{array}{l}n \\
0 \\
0 \\
0 \\
0\end{array}$ & 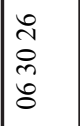 & & & 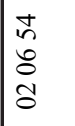 & 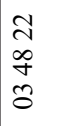 \\
\hline $\begin{array}{l}\stackrel{8}{0} \\
\text { o } \\
=\end{array}$ & $\begin{array}{l}0 \\
0 \\
0 \\
=\end{array}$ & \begin{tabular}{l}
$\dot{H}$ \\
$\tilde{n}$ \\
\multirow{+}{*}{} \\
$\tilde{0}$
\end{tabular} & $\begin{array}{l}\vec{m} \\
\hat{n} \\
\tilde{0}\end{array}$ & 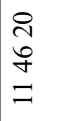 & 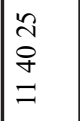 & & & 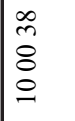 & \begin{tabular}{l}
\multirow{+}{*}{} \\
กิ \\
8 \\
8
\end{tabular} \\
\hline 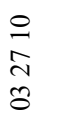 & $\begin{array}{l}= \\
\vdots \\
\vdots \\
0\end{array}$ & $\begin{array}{l}2 \\
\tilde{2} \\
2 \\
\tilde{D} \\
\dot{1}\end{array}$ & 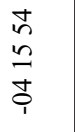 & $\begin{array}{l}\vec{n} \\
\infty \\
\tilde{n} \\
\tilde{\sigma}\end{array}$ & 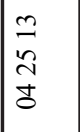 & & & $\begin{array}{l}4 \\
0 \\
9 \\
8\end{array}$ & $\begin{array}{l}d \\
\tilde{n} \\
0 \\
0\end{array}$ \\
\hline $\begin{array}{l}\stackrel{+}{+} \\
\stackrel{+}{d}\end{array}$ & $\begin{array}{l}\text { f } \\
\stackrel{\text { d }}{ }\end{array}$ & $\begin{array}{l}i \\
\AA \\
8\end{array}$ & $\begin{array}{l}\stackrel{0}{0} \\
\stackrel{8}{8}\end{array}$ & $\begin{array}{l}\stackrel{\sim}{\sim} \\
\stackrel{\sim}{\sim}\end{array}$ & $\begin{array}{l}\stackrel{\rho}{\text { I }} \\
\stackrel{\sim}{+}\end{array}$ & $\begin{array}{l}\infty \\
\\
0 \\
1\end{array}$ & $\mid \begin{array}{l}0 \\
1 \\
0 \\
1\end{array}$ & F & $\stackrel{\text { 导 }}{=}$ \\
\hline 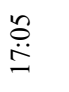 & $\stackrel{\square}{\not}$ & $\underset{0}{\ddot{0}}$ & 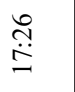 & $\begin{array}{l}\stackrel{8}{8} \\
\stackrel{+}{-}\end{array}$ & $\stackrel{\sim}{\dddot{\alpha}}$ & $\stackrel{\infty}{\stackrel{\infty}{0}}$ & $\stackrel{m}{\ddot{I}}$ & 宊 & 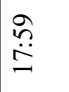 \\
\hline 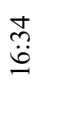 & 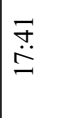 & 㫄 & ભે? & 菊 & 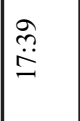 & $\begin{array}{l}\infty \\
\stackrel{\infty}{0} \\
\ddot{0}\end{array}$ & $\underset{\check{I}}{\stackrel{テ}{\Xi}}$ & $\mid \begin{array}{l}\infty \\
\stackrel{\infty}{0} \\
\stackrel{0}{0}\end{array}$ & 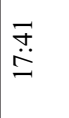 \\
\hline \multirow[t]{3}{*}{ 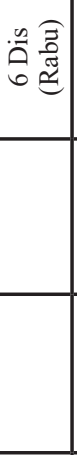 } & 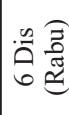 & 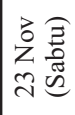 & 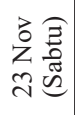 & 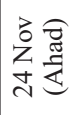 & 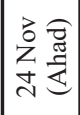 & 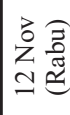 & 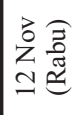 & 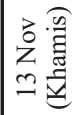 & 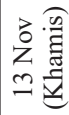 \\
\hline & & $\mid \begin{array}{ll}\vec{y} & \vec{\sigma} \\
\dot{a} & z \\
\dot{0} & \tilde{v}\end{array}$ & 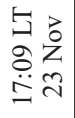 & & & 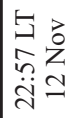 & & & \\
\hline & & 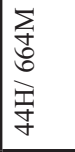 & & & & 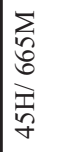 & & & \\
\hline 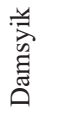 & $\begin{array}{l}\text { 卺 } \\
\sum\end{array}$ & 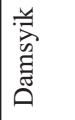 & 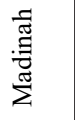 & 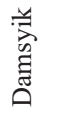 & 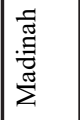 & 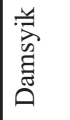 & 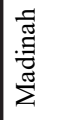 & 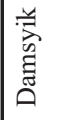 & 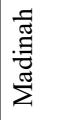 \\
\hline & & i & & & & $\bar{\imath}$ & & & \\
\hline
\end{tabular}




\section{LAMPIRAN B}

Jadual 2: Kemungkinan Tahun Sepadan Dengan Peristiwa

\begin{tabular}{|c|c|c|}
\hline Bil. & Tahun & Kesesuaian \\
\hline 1. & $19 \mathrm{H}$ & $\begin{array}{l}\text { Berkemungkinan kerana ijtimak telah berlaku pada } \\
23 \text { Ogos 640M (Rabu) dan data bulan di Damsyik } \\
\text { pada ketika matahari terbenam hari Khamis, } 24 \\
\text { Ogos } 640 \mathrm{M} \text { menunjukkan hilal telah berumur lebih } \\
41 \text { jam dengan altitud dan elongasi lebih } 13^{\circ} \text { dan } \\
22^{\circ} \text { masing-masing. } \\
\end{array}$ \\
\hline 2. & $20 \mathrm{H}$ & $\begin{array}{l}\text { Tidak berkemungkinan kerana ijtimak telah berlaku } \\
\text { pada } 12 \text { Ogos } 641 \mathrm{M} \text { (Ahad) dan data bulan di } \\
\text { Damsyik pada ketika matahari terbenam hari Isnin, } \\
13 \text { Ogos } 641 \mathrm{M} \text { menunjukkan hilal telah berumur } \\
\text { lebih } 30 \text { jam dengan altitud dan elongasi masing- } \\
\text { masing lebih } 9^{\circ} \text { dan } 15^{\circ} \text {. Hari Khamis hilal sudah } \\
\text { malam keempat. }\end{array}$ \\
\hline 3. & $21 \mathrm{H}$ & $\begin{array}{l}\text { Tidak berkemungkinan kerana ijtimak telah } \\
\text { berlaku pada } 1 \text { Ogos } 642 \mathrm{M} \text { (Khamis) namun data } \\
\text { bulan di Damsyik pada ketika matahari terbenam } \\
\text { hari tersebut menunjukkan hilal baru berumur } 3 \mathrm{j} \\
29 \mathrm{~m} \text { dengan altitud dan elongasi masing-masing } 0^{\circ} \\
\text { dan } 2^{\circ} \text {. }\end{array}$ \\
\hline 4. & $22 \mathrm{H}$ & $\begin{array}{l}\text { Tidak berkemungkinan kerana ijtimak telah } \\
\text { berlaku pada } 21 \text { Julai } 643 \mathrm{M} \text { (Isnin) dan data bulan } \\
\text { di Damsyik pada ketika matahari terbenam hari } \\
\text { Selasa, 22 Julai 643M menunjukkan hilal telah } \\
\text { berumur lebih } 27 \text { jam dengan altitud dan elongasi } \\
\text { masing-masing lebih } 8^{\circ} \text { dan } 12^{\circ} \text {. }\end{array}$ \\
\hline 5. & $23 \mathrm{H}$ & $\begin{array}{l}\text { Tidak berkemungkinan kerana ijtimak telah berlaku } \\
\text { pada } 9 \text { Julai 644M (Jumaat). Hari Khamis, } 8 \text { Julai } \\
\text { 644M hilal belum lahir. }\end{array}$ \\
\hline 6. & $24 \mathrm{H}$ & $\begin{array}{l}\text { Berkemungkinan kerana ijtimak telah berlaku pada } \\
29 \text { Jun } 645 \mathrm{M} \text { (Rabu) dan data bulan di Damsyik } \\
\text { pada ketika matahari terbenam hari Khamis, } 30 \\
\text { Jun } 645 \mathrm{M} \text { menunjukkan hilal telah berumur lebih } \\
34 \text { jam dengan altitud dan elongasi masing-masing } \\
\text { lebih } 14^{\circ} \text { dan } 19^{\circ} \text {. }\end{array}$ \\
\hline
\end{tabular}




\begin{tabular}{|c|c|c|}
\hline 7. & $25 \mathrm{H}$ & $\begin{array}{l}\text { Tidak berkemungkinan kerana ijtimak telah } \\
\text { berlaku pada } 19 \text { Jun } 646 \mathrm{M} \text { (Isnin) dan data bulan } \\
\text { di Damsyik pada ketika matahari terbenam hari } \\
\text { tersebut menunjukkan hilal telah berumur lebih } 18 \\
\text { jam dengan altitud dan elongasi masing-masing } \\
\text { lebih } 8^{\circ} \text { dan } 10^{\circ} \text {. }\end{array}$ \\
\hline 8. & $26 \mathrm{H}$ & $\begin{array}{l}\text { Tidak berkemungkinan kerana ijtimak telah berlaku } \\
\text { pada } 8 \text { Jun } 647 \mathrm{M} \text { (Jumaat). Hari Khamis, } 7 \text { Jun } \\
647 \mathrm{M} \text { hilal belum lahir. }\end{array}$ \\
\hline 9. & $27 \mathrm{H}$ & $\begin{array}{l}\text { Berkemungkinan kerana ijtimak telah berlaku pada } \\
28 \text { Mei } 648 \mathrm{M} \text { (Rabu) dan data bulan di Damsyik } \\
\text { pada ketika matahari terbenam hari Khamis, } 29 \\
\text { Mei } 648 \mathrm{M} \text { menunjukkan hilal telah berumur lebih } \\
36 \text { jam dengan altitud dan elongasi masing-masing } \\
\text { lebih } 16^{\circ} \text { dan } 18^{\circ} \text {. }\end{array}$ \\
\hline 10. & $28 \mathrm{H}$ & $\begin{array}{l}\text { Tidak berkemungkinan kerana ijtimak telah berlaku } \\
\text { pada } 17 \text { Mei } 649 \mathrm{M} \text { (Ahad) dan data bulan di } \\
\text { Damsyik pada ketika matahari terbenam hari Isnin, } \\
18 \text { Mei } 649 \mathrm{M} \text { menunjukkan hilal telah berumur } \\
\text { lebih } 31 \text { jam dengan altitud dan elongasi masing- } \\
\text { masing lebih } 12^{\circ} \text { dan } 14^{\circ} \text {. }\end{array}$ \\
\hline 11. & $29 \mathrm{H}$ & $\begin{array}{l}\text { Tidak berkemungkinan kerana ijtimak telah } \\
\text { berlaku pada } 6 \text { Mei } 650 \mathrm{M} \text { (Khamis) namun data } \\
\text { bulan di Damsyik pada ketika matahari terbenam } \\
\text { hari tersebut menunjukkan hilal baru berumur } 6 \mathrm{j} \\
31 \mathrm{~m} \text { dengan altitud dan elongasi masing-masing } \\
\text { lebih } 1^{\circ} \text { dan } 5^{\circ} \text {. }\end{array}$ \\
\hline 12. & $30 \mathrm{H}$ & $\begin{array}{l}\text { Tidak berkemungkinan kerana ijtimak telah } \\
\text { berlaku pada } 25 \text { April } 651 \mathrm{M} \text { (Isnin) dan data bulan } \\
\text { di Damsyik pada ketika matahari terbenam hari } \\
\text { Selasa, } 26 \text { April } 651 \mathrm{M} \text { menunjukkan hilal telah } \\
\text { berumur lebih } 27 \text { jam dengan altitud dan elongasi } \\
\text { masing-masing lebih } 11^{\circ} \text { dan } 13^{\circ} \text {. }\end{array}$ \\
\hline 13. & $31 \mathrm{H}$ & $\begin{array}{l}\text { Tidak berkemungkinan kerana ijtimak telah berlaku } \\
\text { pada } 14 \text { April } 652 \mathrm{M} \text { (Sabtu) dan data bulan di } \\
\text { Damsyik pada ketika matahari terbenam hari Ahad, } \\
15 \text { April } 652 \mathrm{M} \text { menunjukkan hilal telah berumur } \\
\text { lebih } 40 \text { jam dengan altitud dan elongasi masing- } \\
\text { masing lebih } 19^{\circ} \text { dan } 21^{\circ} \text {. }\end{array}$ \\
\hline
\end{tabular}




\begin{tabular}{|c|c|c|}
\hline 14. & $32 \mathrm{H}$ & $\begin{array}{l}\text { Berkemungkinan kerana ijtimak telah berlaku pada } \\
3 \text { April } 653 \mathrm{M} \text { (Rabu) dan data bulan di Damsyik } \\
\text { pada ketika matahari terbenam hari Khamis, } 4 \\
\text { April } 653 \mathrm{M} \text { menunjukkan hilal telah berumur lebih } \\
25 \text { jam dengan altitud dan elongasi masing-masing } \\
\text { lebih } 12^{\circ} \text { dan } 14^{\circ} \text {. }\end{array}$ \\
\hline 15. & $33 \mathrm{H}$ & $\begin{array}{l}\text { Tidak berkemungkinan kerana ijtimak telah } \\
\text { berlaku pada } 24 \text { Mac } 654 \mathrm{M} \text { (Isnin) dan data bulan } \\
\text { di Damsyik pada ketika matahari terbenam hari } \\
\text { Selasa, } 25 \text { Mac } 654 \mathrm{M} \text { menunjukkan hilal telah } \\
\text { berumur lebih } 32 \text { jam dengan altitud dan elongasi } \\
\text { masing-masing lebih } 16^{\circ} \text { dan } 17^{\circ} \text {. }\end{array}$ \\
\hline 16. & $34 \mathrm{H}$ & $\begin{array}{l}\text { Tidak berkemungkinan kerana ijtimak telah berlaku } \\
\text { pada } 13 \mathrm{Mac} 655 \mathrm{M} \text { (Jumaat). Hari Khamis, } 12 \mathrm{Mac} \\
655 \mathrm{M} \text { hilal belum lahir. }\end{array}$ \\
\hline 17. & $35 \mathrm{H}$ & $\begin{array}{l}\text { Berkemungkinan kerana ijtimak telah berlaku pada } \\
2 \text { Mac } 656 \mathrm{M} \text { (Rabu) dan data bulan di Damsyik } \\
\text { pada ketika matahari terbenam hari Khamis, } 3 \text { Mac } \\
656 \mathrm{M} \text { menunjukkan hilal telah berumur lebih } 36 \\
\text { jam dengan altitud dan elongasi masing-masing } \\
\text { lebih } 14^{\circ} \text { dan } 16^{\circ} \text {. }\end{array}$ \\
\hline 18. & $36 \mathrm{H}$ & $\begin{array}{l}\text { Tidak berkemungkinan kerana ijtimak telah berlaku } \\
\text { pada } 19 \text { Februari } 657 \mathrm{M} \text { (Ahad) dan data bulan } \\
\text { di Damsyik pada ketika matahari terbenam hari } \\
\text { Isnin, } 20 \text { Februari } 657 \mathrm{M} \text { menunjukkan hilal telah } \\
\text { berumur lebih } 36 \text { jam dengan altitud dan elongasi } \\
\text { masing-masing lebih } 13^{\circ} \text { dan } 15^{\circ} \text {. } \\
\end{array}$ \\
\hline 19. & $37 \mathrm{H}$ & $\begin{array}{l}\text { Tidak berkemungkinan kerana ijtimak telah berlaku } \\
\text { pada } 8 \text { Februari } 658 \mathrm{M} \text { (Khamis) namun data bulan } \\
\text { di Damsyik pada ketika matahari terbenam hari } \\
\text { tersebut menunjukkan hilal baru berumur } 11 \mathrm{j} 03 \mathrm{~m} \\
\text { dengan altitud dan elongasi masing-masing } 2^{\circ} \\
\text { dan } 4^{\circ} \text {, mustahil kelihatan dengan disaksikan oleh } \\
\text { orang ramai melalui mata kasar. }\end{array}$ \\
\hline
\end{tabular}




\begin{tabular}{|c|c|c|}
\hline 20. & $38 \mathrm{H}$ & $\begin{array}{l}\text { Tidak berkemungkinan kerana ijtimak telah berlaku } \\
\text { pada } 28 \text { Januari } 659 \mathrm{M} \text { (Isnin) dan data bulan di } \\
\text { Damsyik pada ketika matahari terbenam hari } \\
\text { Selasa, } 29 \text { Januari } 659 \mathrm{M} \text { menunjukkan hilal telah } \\
\text { berumur lebih } 26 \text { jam dengan altitud dan elongasi } \\
\text { masing-masing lebih } 10^{\circ} \text { dan } 13^{\circ} \text {. }\end{array}$ \\
\hline 21. & $39 \mathrm{H}$ & $\begin{array}{l}\text { Tidak berkemungkinan kerana ijtimak telah berlaku } \\
\text { pada } 18 \text { Januari } 660 \mathrm{M} \text { (Sabtu) dan data bulan di } \\
\text { Damsyik pada ketika matahari terbenam hari Ahad, } \\
19 \text { Januari } 660 \mathrm{M} \text { menunjukkan hilal telah berumur } \\
\text { lebih } 36 \text { jam dengan altitud dan elongasi masing- } \\
\text { masing lebih } 16^{\circ} \text { dan } 20^{\circ} \text {. }\end{array}$ \\
\hline 22. & $40 \mathrm{H}$ & $\begin{array}{l}\text { Berkemungkinan kerana ijtimak telah berlaku pada } \\
6 \text { Januari } 661 \mathrm{M} \text { (Rabu) dan data bulan di Damsyik } \\
\text { pada ketika matahari terbenam hari Khamis, } 7 \\
\text { Januari } 661 \mathrm{M} \text { menunjukkan hilal telah berumur } \\
\text { lebih } 20 \text { jam dengan altitud dan elongasi lebih } 7^{\circ} \\
\text { dan } 11^{\circ} \text { masing-masing. }\end{array}$ \\
\hline 23. & $41 \mathrm{H}$ & $\begin{array}{l}\text { Tidak berkemungkinan kerana ijtimak telah } \\
\text { berlaku pada } 27 \text { Disember } 661 \mathrm{M} \text { (Isnin) dan data } \\
\text { bulan di Damsyik pada ketika matahari terbenam } \\
\text { hari Selasa, } 28 \text { Disember } 661 \mathrm{M} \text { menunjukkan hilal } \\
\text { telah berumur lebih } 31 \text { jam dengan altitud dan } \\
\text { elongasi masing-masing lebih } 10^{\circ} \text { dan } 16^{\circ} \text {. }\end{array}$ \\
\hline 24. & $42 \mathrm{H}$ & $\begin{array}{l}\text { Tidak berkemungkinan kerana ijtimak telah berlaku } \\
\text { pada } 16 \text { Disember } 662 \mathrm{M} \text { (Jumaat). Hari Khamis, } \\
15 \text { Disember } 662 \mathrm{M} \text { hilal belum lahir. }\end{array}$ \\
\hline 25. & $43 \mathrm{H}$ & $\begin{array}{l}\text { Berkemungkinan kerana ijtimak telah berlaku } \\
\text { pada } 5 \text { Disember } 663 \mathrm{M} \text { (Selasa) dan data bulan di } \\
\text { Damsyik pada ketika matahari terbenam hari Rabu, } \\
6 \text { Disember } 663 \mathrm{M} \text { menunjukkan hilal telah berumur } \\
\text { lebih } 24 \text { jam dengan altitud dan elongasi lebih } 3^{\circ} \\
\text { dan } 11^{\circ} \text { masing-masing. Hari Khamis, } 7 \text { Disember } \\
663 \mathrm{M} \text { sudah cukup besar untuk kelihatan dengan } \\
\text { mata kasar dan disaksikan oleh orang ramai. }\end{array}$ \\
\hline
\end{tabular}




\begin{tabular}{|c|c|l|}
\hline 26. & $44 \mathrm{H}$ & $\begin{array}{l}\text { Tidak berkemungkinan kerana ijtimak telah berlaku } \\
\text { pada 23 November 664M (Sabtu) dan data bulan di } \\
\text { Damsyik pada ketika matahari terbenam hari Ahad, } \\
24 \text { November 664M menunjukkan hilal telah } \\
\text { berumur lebih 24 jam dengan altitud dan elongasi } \\
\text { masing-masing lebih } 2^{\circ} \text { dan } 11^{\circ} .\end{array}$ \\
\hline 27. & $45 \mathrm{H}$ & $\begin{array}{l}\text { Tidak berkemungkinan kerana ijtimak telah } \\
\text { berlaku pada } 12 \text { November } 665 \mathrm{M} \text { (Rabu) dan data } \\
\text { bulan di Damsyik pada ketika matahari terbenam } \\
\text { hari Khamis, 13 November 665M menunjukkan } \\
\text { hilal baru berumur lebih 17 jam dengan altitud dan } \\
\text { elongasi lebih } 0^{\circ} \text { dan } 10^{\circ} \text { masing-masing, mustahil } \\
\text { kelihatan dengan disaksikan oleh orang ramai } \\
\text { melalui mata kasar. }\end{array}$ \\
\hline
\end{tabular}

Sumber: Analisis Penyelidik 